DOE/WIPP 02-3283

Revision 0, August 2003

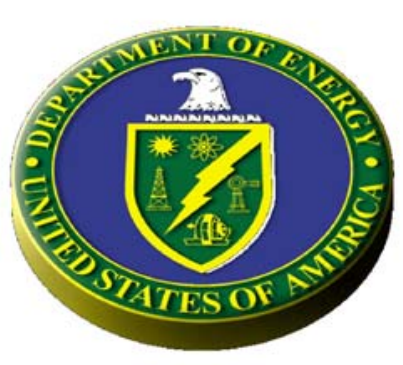

\title{
RH Packaging Program Guidance
}


DOE/WIPP 02-3283

Revision 0, August 2003

RH Packaging Program Guidance

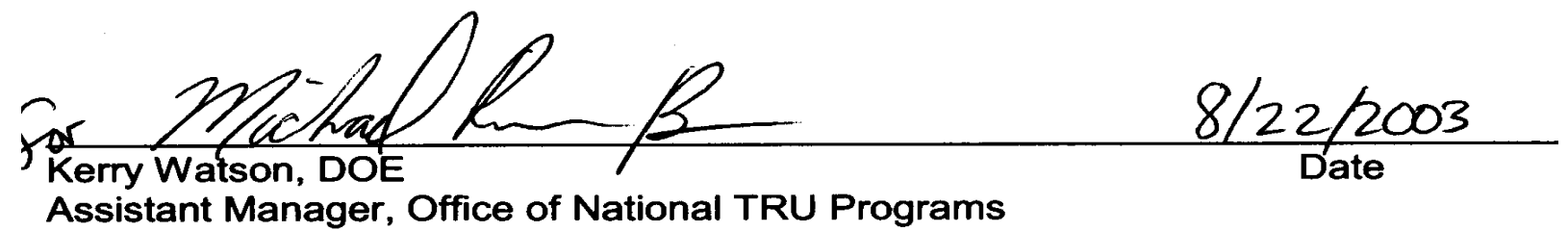

Processing and final preparation of this paper was performed by Washington TRU Solutions LLC, the Waste Isolation Pilot Plant (WIPP) Management and Operating (M\&O) Contractor under US Department of Energy contract number DE-AC04-01AL66444. 
This document has been submitted as required to:

Office of Scientific and Technical Information

P.O. Box 62

Oak Ridge, TN 37831

(615) $576-8401$

Additional Information about this document may be obtained by calling (800) 336-9477. Copies may be obtained by contacting the National Technical Information Service, US Department of Commerce, 5285 Port Royal Road, Springfield, VA 22101. 


\section{RECORD OF REVISION}

Revision Reason for Revision/Change

$0 \quad$ New RH Packaging Program Guidance. This manual must be used with DOE/WIPP 02-3284, RH Packaging Operations Manual, and DOE/WIPP 02-3285, RH Packaging Maintenance Manual. 


\begin{tabular}{|c||}
\hline M\&O CONTRACTOR TECHNICAL REVIEW ORGANIZATIONS \\
\hline WASHINGTON TRU SOLUTIONS \\
\hline CBFO REVIEW ORGANIZATIONS \\
\hline NATIONAL TRU WASTE PROGRAM \\
QUALITY ASSURANCE \\
EDITORIAL \\
\hline
\end{tabular}




\section{TABLE OF CONTENTS}

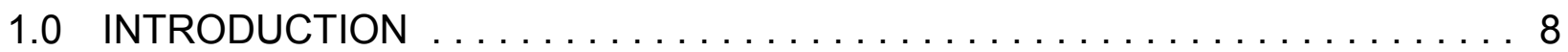

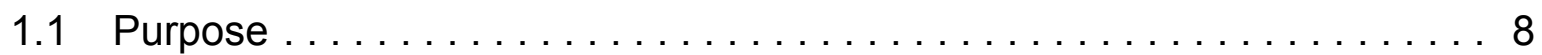

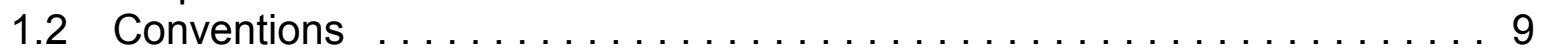

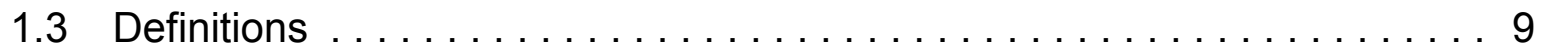

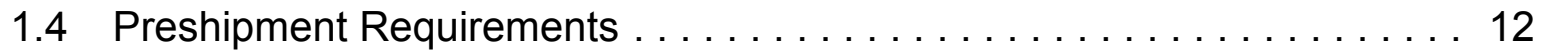

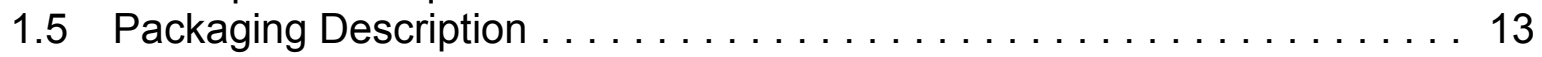

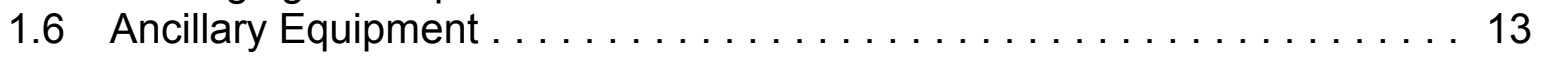

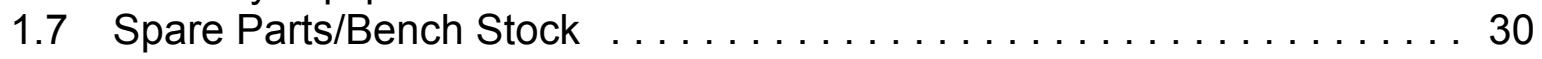

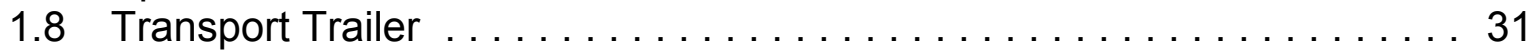

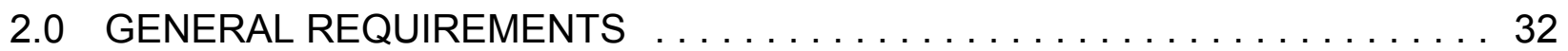

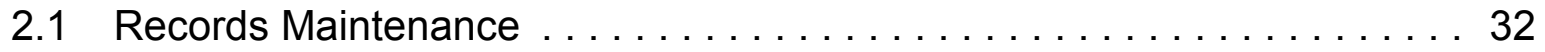

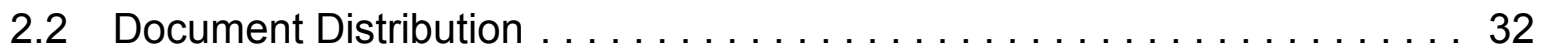

2.3 Approved Work/Periodic Maintenance Instructions . . . . . . . . . 32

2.4 Material Control . . . . . . . . . . . . . . . . . . . . . . . 32

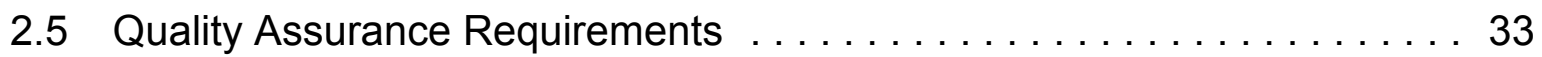

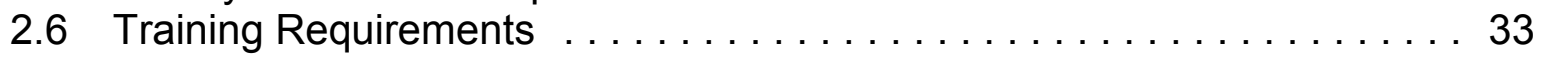

2.7 Maximum Packaging Weights $\ldots \ldots \ldots \ldots \ldots \ldots \ldots \ldots \ldots \ldots \ldots \ldots \ldots \ldots \ldots$

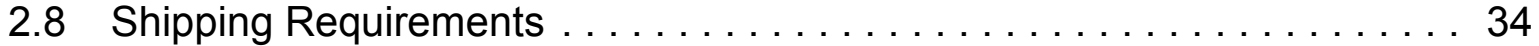

2.9 Shipment Scheduling $\ldots \ldots \ldots \ldots \ldots \ldots \ldots \ldots \ldots \ldots \ldots \ldots \ldots \ldots \ldots$

2.10 Nonconformance Reports . . . . . . . . . . . . . . . . . . 34

3.0 PAYLOAD PREPARATION $\ldots \ldots \ldots \ldots \ldots \ldots \ldots \ldots \ldots \ldots \ldots \ldots \ldots \ldots \ldots \ldots \ldots$

4.0 PACKAGE OPERATING INSTRUCTIONS $\ldots \ldots \ldots \ldots \ldots \ldots \ldots \ldots \ldots$

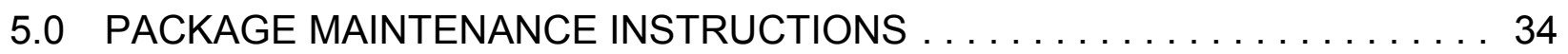

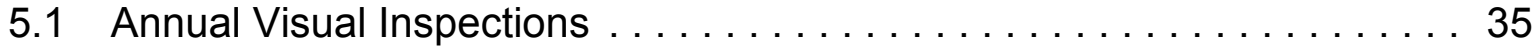

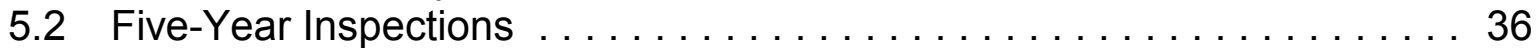

5.3 Packaging Component Replacement Schedule $\ldots \ldots \ldots \ldots \ldots \ldots . . \ldots 37$

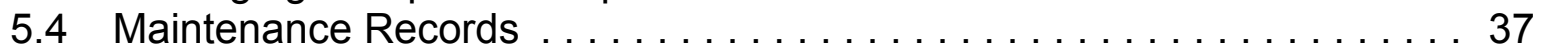

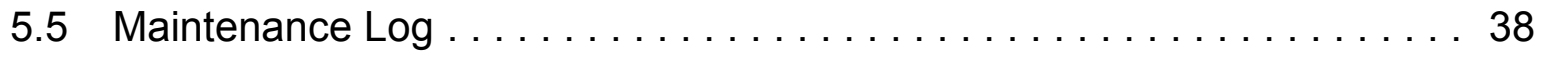

5.6 Maintenance Due Labels $\ldots \ldots \ldots \ldots \ldots \ldots \ldots \ldots \ldots \ldots \ldots \ldots$

6.0 PACKAGE MAINTENANCE LEAKAGE RATE TESTING $\ldots \ldots \ldots \ldots \ldots .44$

7.0 PACKAGE STRUCTURAL PRESSURE TESTING $\ldots \ldots \ldots \ldots \ldots \ldots \ldots 4$

Attachment A - Work Instruction Format $\ldots \ldots \ldots \ldots \ldots \ldots \ldots \ldots \ldots \ldots \ldots \ldots \ldots$

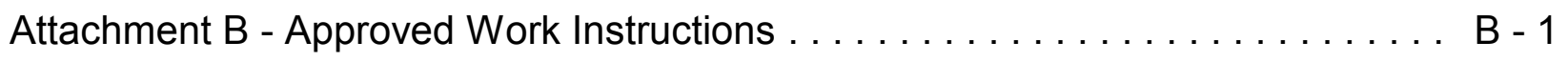

Attachment C - RH Packaging Qualification Requirements $\ldots \ldots \ldots \ldots \ldots$ C - 1 


\section{LIST OF FIGURES}

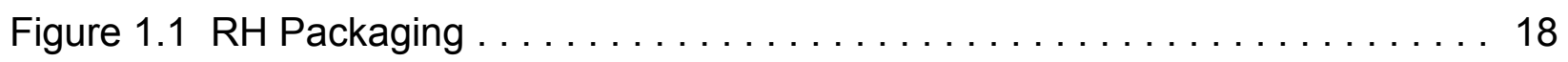

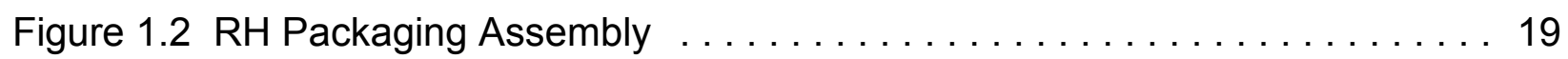

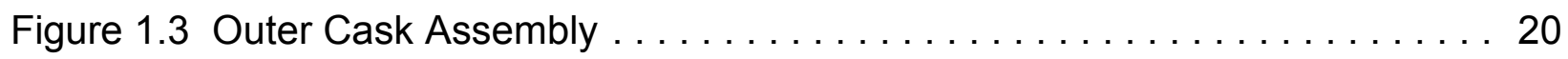

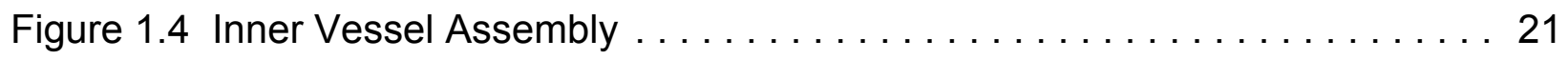

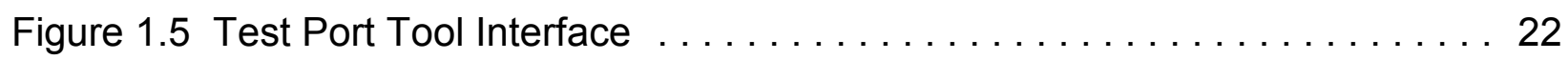

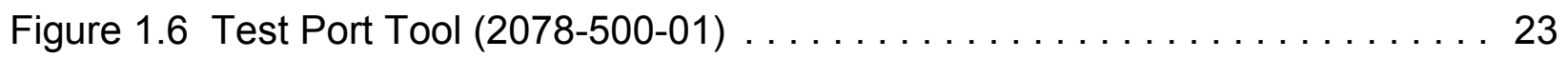

Figure 1.7 Impact Limiter Components $\ldots \ldots \ldots \ldots \ldots \ldots \ldots \ldots \ldots \ldots \ldots \ldots$

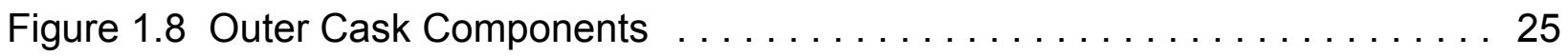

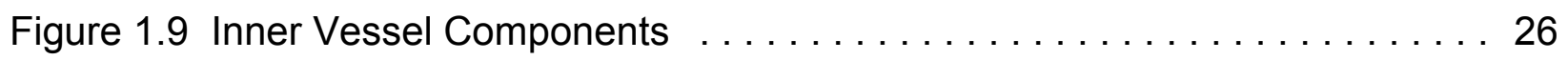

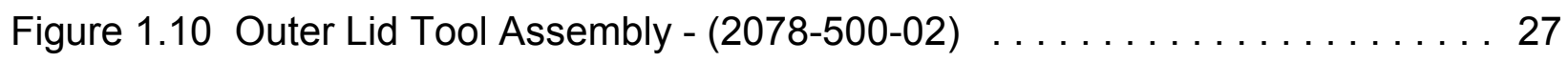

Figure 1.11 Inner Lid Tool Assembly - (2078-500-03) . . . . . . . . . . . 28

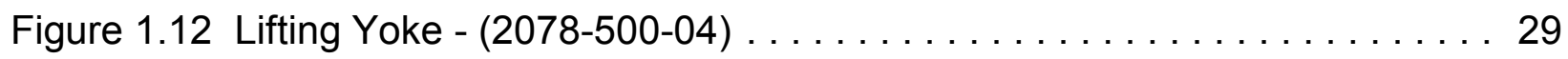

Figure 5.1 Maintenance Record $\ldots \ldots \ldots \ldots \ldots \ldots \ldots \ldots \ldots \ldots \ldots \ldots \ldots \ldots \ldots \ldots \ldots \ldots \ldots$

\section{LIST OF TABLES}

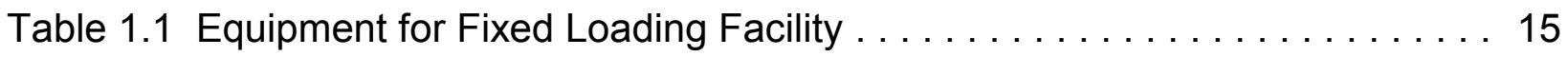

Table 1.2 Recommended User Supplied Tools, Equipment, and Consumables . . . 16

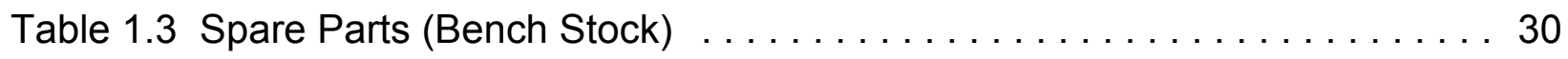

Table 5.1 Annual Visual Inspections, Acceptance Criteria, and Corrective Action . 41

Table 5.2 Annual Component Inspection, Acceptance Criteria, and Corrective Action

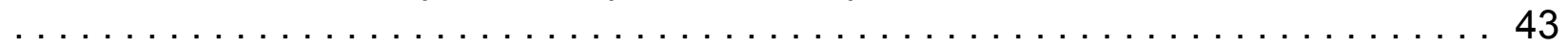

Table 5.3 Component Replacement Schedule and Work Instruction . . . . . . . . 44 


\subsection{INTRODUCTION}

\subsection{Purpose}

The purpose of this program guidance document is to provide technical requirements for use, operation, inspection, and maintenance of the RH-TRU 72-B Waste Shipping Package and directly related components. This document complies with the requirements as specified in the RH-TRU 72-B Safety Analysis Report for Packaging (SARP), and Nuclear Regulatory Commission (NRC) Certificate of Compliance ( $C$ of $C$ ) 9212. If there is a conflict between this document and the SARP and/or $\mathrm{C}$ of $\mathrm{C}$, the SARP and/or $\mathrm{C}$ of $\mathrm{C}$ shall govern. The $\mathrm{C}$ of $\mathrm{C}$ states: "...each package must be prepared for shipment and operated in accordance with the procedures described in Chapter 7.0, 'Operating Procedures,' of the application." It further states: "...each package must be tested and maintained in accordance with the procedures described in Chapter 8.0, 'Acceptance Tests and Maintenance Program of the Application."' Chapter 9.0 of the SARP tasks the Waste Isolation Pilot Plant (WIPP) Management and Operating (M\&O) contractor with assuring the packaging is used in accordance with the requirements of the $C$ of $C$. Because the packaging is NRCapproved, users need to be familiar with 10 CFR §71.11, "Deliberate Misconduct." Any time a user suspects or has indications that the conditions of approval in the $C$ of $C$ were not met, the Carlsbad Field Office (CBFO) shall be notified immediately. CBFO will evaluate the issue and notify the NRC if required.

This document details the instructions to be followed to operate, maintain, and test the RH-TRU 72-B packaging. This Program Guidance standardizes instructions for all users. Users shall follow these instructions. Following these instructions assures that operations are safe and meet the requirements of the SARP.

This document is available on the Internet at: http://www.ws/library/t2omi/t2omi.htm. Users are responsible for ensuring they are using the current revision and change notices.

Sites may prepare their own document using the word-for-word steps in this document, in sequence, including Notes and cautions. Site specific information may be included as necessary. The document, and revisions, must then be submitted to CBFO at sitedocuments@wipp.ws for approval. A copy of the approval letter from CBFO shall be available for audit purposes.

Users may develop site-specific procedures addressing preoperational activities, quality assurance (QA), hoisting and rigging, and radiation health physics to be used with the instructions contained in this document.

Users may recommend changes to this document by submitting their recommendations (in writing) to the WIPP M\&O Contractor RH Packaging Maintenance Engineer for evaluation. If approved, the change(s) will be incorporated into this document for use by ALL users. Before first use and every 12 months after, user sites will be audited to this document to ensure compliance. They will also be audited within one year from the effective date of revisions to this document. 


\subsection{Conventions}

The following conventions are used to standardize the language used in this document:

• $\quad$ The words "will," "shall" and "must" denote requirements.

- $\quad$ The word "should" denotes a recommendation.

- $\quad$ The word "may" denotes permission, neither a requirement nor a recommendation.

- $\quad$ The word "check" is used to determine the condition or status.

- $\quad$ The word "verify" is used to confirm a condition.

- $\quad$ Parts shall be identified with the part number and name as listed in the work instructions (WI).

- $\quad$ Standard abbreviations (not symbols) will be written out to express measurements and dimensions. For example, use 10 feet or $10 \mathrm{ft}$, but not 10'.

- Cautions and notes shall not be used as instruction steps.

\subsection{Definitions}

- Annual Maintenance - Periodic maintenance performed at one-year intervals.

- Bench Stock - The on-hand supply of packaging components.

- $\quad$ Carlsbad Field Office (CBFO) - The U.S. Department of Energy (DOE) office responsible for managing the packaging and transportation activities associated with defense-generated contact-handled $(\mathrm{CH})$ and remote-handled $(\mathrm{RH})$ transuranic (TRU) materials.

- Central Monitoring Room (CMR) - A communication center where the WIPP $M \& O$ contractor can be reached during normal hours.

- $\quad$ Certificate of Compliance (C of $C$ ) - A document issued by the Nuclear Regulatory Commission (NRC), approving the design of a specific radioactive materials packaging for use with specified payload limitations.

- Certified Waste - Waste confirmed to comply with acceptance criteria under an approved waste certification program.

- $\quad$ Five-Year Maintenance - Periodic maintenance performed at five-year intervals.

- Inspection/Inspect - Unless otherwise addressed in this document, this refers to personnel performing visual examination activities.

- $\quad$ Leak Check Due Tag - A tag attached to the outer cask pad eye. This tag shows a containment $\mathrm{O}$-ring has been replaced and a maintenance leakage rate 
test is required before the next radioactive shipment. The reverse side of the tag will be marked in indelible ink stating which containment O-ring was replaced.

- Maintenance Leakage Rate Test - This includes leak tests to confirm that maintenance, repair, or component replacement have not degraded the containment system.

- Maintenance Record - A list of maintenance performed that becomes a permanent part of the documentation record.

- Major Maintenance - Consists of all repairs requiring welding or machining to correct a deficiency that affects the integrity of packaging or components. (Note: major repairs and major component replacements are the responsibility of the WIPP M\&O contractor). These repairs/replacements will be performed at a maintenance facility designated and approved by the WIPP M\&O contractor.

- $\quad$ Minor Maintenance - This consists of all repairs that can be readily accomplished and require no special tools, supplies, equipment, or highly skilled personnel, such as scratches on the sealing surface. (Note: minor repairs and minor component replacements shall be performed at sites that have the necessary equipment and qualified personnel to perform these tasks.)

- $\quad$ Mobile Loading Unit (MLU) - Trailer-mounted equipment necessary to load/unload a packaging at locations where fixed loading/unloading facilities do not exist.

- $\quad$ Nonconformance Report (NCR) - A document that identifies and records a nonconforming condition, and the action taken for the disposition of the nonconformance. Disposition of nonconforming items includes review, accept, reject, rework, use-as-is, or repair following approved instructions. All occurrences of NCRs require formal disposition by the WIPP M\&O contractor.

- Nuclear Regulatory Commission (NRC) - The federal agency that certifies the design, manufacture and QA of radioactive materials shipment packaging by certifying that all packaging meets the design requirements specified in 10 Code of Federal Regulations (CFR) Part 71 "Packaging and Transportation of Radioactive Material."

- Out-of-Service - An administrative condition of the packaging that states it is not useable for radioactive shipments. When a packaging is out-of-service, a tag shall be attached that states the out-of-service condition.

- Owner - The organization to which the NRC C of C is issued (e.g., for DOE $\mathrm{RH}-\mathrm{TRU}$ 72-B shipping packages).

- $\quad$ Package - Packaging together with its radioactive contents as presented for transport. 
- $\quad$ Packaging - The assembly of components needed to comply with the packaging requirements of 10 CFR Part 71. It may consist of one or more receptacles, absorbent materials, spacing structures, thermal insulation, radiation shielding, and devices for cooling or absorbing mechanical shock. The vehicle, tie-down system, and auxiliary equipment may be designated as part of the packaging.

- $\quad$ Periodic Leakage Rate Test - Leak tests to verify containment boundary integrity.

- $\quad$ Periodic Maintenance (PM) - All maintenance activities performed annually or another periodic interval. Periodic maintenance activities listed in Section 5.0, Package Maintenance Instructions, will normally be performed at a maintenance facility designated and approved by the WIPP M\&O contractor.

- $\quad$ Preshipment Leakage Rate Test - Leak-tests performed during assembly of a loaded package.

- $\quad$ Remote-Handled Transuranic (RH TRU) Waste - Transuranic waste with an external radiation dose rate exceeding $200 \mathrm{millirem} / \mathrm{hr}$ and less than or equal to $1,000 \mathrm{rem} / \mathrm{hr}$ at the waste container's surface.

- $\quad$ Safety Analysis Report for Packaging (SARP) - The official application to a packaging licensing agency (DOE or NRC) containing a demonstration of packaging effectiveness and ability to achieve the requirements in 10 CFR Part 71. The SARP is the controlling document for all packaging operations and maintenance.

- $\quad$ Test and Handling (T\&H) Equipment - Equipment required to be on hand to load, unload, and test the packaging.

- Transportation Tracking and Communication System (TRANSCOM) - A vehicle tracking system for sensitive DOE shipments using satellite communications and interpretive computer software. The system allows the tracking of selected shipments without driver input. Two-way communications are possible between the driver and the CMR/TCC, or from selected users via the TCC to another user.

- Transuranic Content Codes (TRUCON) - A uniform system grouping waste forms with similar characteristics for purposes of shipment in the packaging.

- Transuranic (TRU) Waste - Waste containing more than 100 nanocuries of alpha-emitting TRU isotopes per gram (with half-lives greater than 20 years), except:

- High-level radioactive waste

- Waste that the Secretary has determined, with concurrence of the Administrator, does not need the isolation required by the disposal regulations 
- Waste that the NRC has approved for disposal on a case-by-case basis according to 10 CFR Part 61, "Disposal of Radioactive Waste"

- $\quad$ Remote Handled (RH) Transuranic Waste Authorized Methods for Payload Control (TRAMPAC) - The document that provides acceptable methods of preparation and characterization to qualify TRU waste as payload for transport in the packaging.

- Users - Those organizations, both DOE and commercial, authorized by the DOE or NRC to use the DOE-owned, NRC-approved packaging to ship or receive waste.

- Visual Inspection - An inspection of component attributes, usually performed using a checklist with acceptance and rejection criteria.

- WIPP - The Waste Isolation Pilot Plant.

- Work Instruction (WI) - A document containing detailed steps for performing specific maintenance activities.

- Work Control - The process by which all scheduled and unscheduled maintenance is initiated, prioritized, performed, and documented.

\subsection{Preshipment Requirements}

Before making the initial shipment of TRU waste, the shipper must submit an RH Transuranic Waste Authorized Methods for Payload Control (TRAMPAC) and associated QA plans to CBFO for review at sitedocuments@wipp.ws. Additional guidance may be obtained by contacting the WIPP M\&O contractor. A new user must also perform the following:

- Determine whether a fixed facility or a mobile loading unit (not available yet) will be required. The facility must meet minimum size and height requirements to conduct loading operations. Minimum electrical power requirements for operation of a crane and other equipment must be considered. For a mobile loading unit the facility does not need to obtain the consumables and bench stock of spare parts.

- Obtain the testing and handling equipment (see Table 1.1).

- Obtain the consumables and bench stock of spare parts (see Table 1.2 and Table 1.3).

- $\quad$ Prepare and approve site procedures (QA, hoisting and rigging, preoperational checks, and radiation health physics) for use during packaging operations.

- Obtain authorization to use, and complete training to operate, the DOE TRANSCOM satellite-based shipment tracking system. 
- $\quad$ Complete training and site-specific qualification of personnel to perform packaging operations. All Subject Matter Experts (SME) shall be evaluated by the M\&O Contractor RH Packaging Maintenance Engineer and signed off on their knowledge of the 72-B cask operations and maintenance before training others to that knowledge.

- $\quad$ Successfully complete a certification audit by the CBFO/WIPP M\&O contractor to ship TRU waste in RH packaging. Initial certification will include observation of a "DUMMY" loading operation and performance of a randomly selected Maintenance Instruction, to include preparation of associated documentation. (This does not apply to small-quantity sites with shipments loaded by other trained personnel.)

\subsection{Packaging Description}

The RH-TRU 72-B Cask is a U.S. Department of Transportation (DOT) Type B packaging certified by the NRC. The packaging is a stainless steel, lead-shielded cask designed to provide double containment for shipment of TRU materials. The packaging consists of a cylindrical stainless steel and lead cask body, a separate inner stainless steel vessel (IV), and foam-filled impact limiters at each end of the cask body.

The outer cask body $(\mathrm{OC})$ consists of a $1-1 / 2$ in. thick, $41-1 / 8$ in. outer diameter stainless steel outer shell, and a 1 in. thick, $32-3 / 8$ in. inside diameter stainless steel inner shell, with $1-7 / 8$ in. of lead shielding between the two shells. The cask bottom is 5 in. thick stainless steel plate. The cask is closed by a 6 in. thick stainless steel lid, and eighteen $1-1 / 4$ in. diameter bolts. The main closure lid has a double bore-type O-ring seal. The containment seal is the inner butyl O-ring seal, which is leak-testable. The cask lid has a gas sampling port and a seal test port. The gas sampling port is a containment boundary and is sealed with a leak-testable butyl O-ring seal.

The separate inner vessel consists of a $3 / 8$ in. thick, 32 in. outside diameter stainless steel shell, and a $1-1 / 2$ in. thick stainless steel bottom plate. The inner vessel is closed by a $6-1 / 2$ in. thick stainless steel lid, and eight $7 / 8$ in. diameter bolts. The inner vessel closure lid has three bore-type O-ring seals. The containment seal is the middle butyl O-ring seal, which is leak-testable. The inner vessel lid has a helium backfill port and a combination vent/sampling port that are sealed with leak-testable butyl O-ring seals.

A polyurethane foam-filled stainless steel impact limiter is attached to each end of the cask body using six $1-1 / 4$ in. diameter bolts. The radioactive contents are packaged within a carbon steel waste canister that is placed in the inner vessel.

\subsection{Ancillary Equipment}

\subsubsection{Test Port Tool}

Two test port tools are provided by the M\&O Contractor RH Packaging Maintenance Engineer as shown in Table 1.1, Equipment for Fixed Loading Facility. Quantities are sufficient for user site requirements with provisions for limited spares. Replacements 
for defective tools are provided by the M\&O Contractor RH Packaging Maintenance Engineer on an exchange basis.

Before each use, the tool should be inspected for thread and O-ring damage and free movement of moving parts. Replacement O-rings are listed on Figure 1.6, Test Port Tool, and in Table 1.2, Recommended User Supplied Tools, Equipment, and Consumables.

The OC/IV Test Port Tool provides for:

- Installing and removing port closure bolts

- $\quad$ Venting OC and IV cavities

- $\quad$ Checking the lid and port closure bolt containment O-rings for leakage (See Figure 1.5, Test Port Tool Interface.)

\subsubsection{Tools, Equipment, and Consumables for RH Packaging Loading}

Table 1.1 lists the tools and equipment required for fixed loading facility packaging operations. Quantities listed are for a fixed facility with limited spares. Test port tools are provided by the M\&O contractor through the RH Packaging Maintenance Engineer. Descriptions of the major tools and their uses are as follows:

- INNER LID TOOL - The inner lid tool is used for removing and replacing the IV lid. This tool may only be lifted by the pintle lid lifting device. The removable bar in the center is for operator assistance when placing the tool on the lid. (See Figure 1.11, Inner Lid Tool Assembly.) (2078-500-03)

- OUTER LID TOOL - The outer lid tool can be used for lifting either the inner or outer lid with the use of appropriate rigging and a crane hook. (See Figure 1.10 Outer Lid Tool Assembly.) (2078-500-02)

- $\quad$ CRANE LOAD CELL - A crane load cell must be used when lifting the following components:

- IV lid

- OC lid

- Impact limiters

- Inner vessel

- $\quad$ ROAD CASK LIFTING YOKE - The road cask lifting yoke is used for the following:

- Lift cask off trailer - Rotate, remove, and install the road cask

- Center pivot trailer - Remove and install the road cask (See Figure 1.12, Lifting Yoke.) 


\begin{tabular}{|c|c|c|c|}
\hline Tool & Quantity & Spares & $\sqrt{1}$ \\
\hline $\begin{array}{l}\text { Test Port Tool } \\
\text { (see Figure 1.6) (Drawing \# 164-F-001) }\end{array}$ & 2 & 1 & \\
\hline Helium Leak Detector & 1 (user supplied) & Optional & \\
\hline Calibrated Standard Leak & 1 (user supplied) & Optional & \\
\hline Calibrated Temperature Measuring Device & 1 (user supplied) & Optional & \\
\hline Calibrated Barometer & 1 (user supplied) & Optional & \\
\hline $\begin{array}{l}\text { Pintle Lid Lifting Device } \\
\text { (Drawing \# 411-L-013 W1-W5) }\end{array}$ & 1 (user supplied) & Optional & \\
\hline Calibrated Crane Load Cell & 1 (user supplied) & Optional & \\
\hline $\begin{array}{l}\text { Outer Lid Tool } \quad(2078-500-02) \\
\text { (see Figure 1.10) (Drawing \# 412-Z-004-W7, W8) }\end{array}$ & 1 (user supplied) & Optional & \\
\hline $\begin{array}{lr}\text { Inner Lid Tool } & (2078-500-03) \\
\text { (see Figure 1.11) } & \text { (Drawing \# 412-Z-004-W9, W10) }\end{array}$ & 1 (user supplied) & Optional & \\
\hline $\begin{array}{l}\text { Road Cask Lifting Yoke } \quad(2078-500-04) \\
\text { (see Figure 1.12) (drawing \# 412-Z-004W11W12) }\end{array}$ & 1 (user supplied) & Optional & \\
\hline
\end{tabular}




\section{Table 1.2 Recommended User Supplied Tools, Equipment, and Consumables}

\begin{tabular}{|c|c|c|}
\hline Item & Application & $\checkmark$ \\
\hline Compressed-air Blow Gun & Clean threads, cavities with argon gas & \\
\hline 12 in. Adjustable Wrench $\times 2$ & $\begin{array}{l}\text { Fastening gauges to compressed gas } \\
\text { bottles }\end{array}$ & \\
\hline $1 / 4$ in. Flat Tip Screwdriver & Hose clamps on leak test equipment & \\
\hline $\begin{array}{l}\text { Torque Wrenches: } \\
\cdot 600 \text { to } 700 \mathrm{lb}-\mathrm{ft} \\
\cdot 100 \text { to } 200 \mathrm{lb}-\mathrm{ft} \\
\cdot 15 \text { to } 20 \mathrm{lb}-\mathrm{ft}\end{array}$ & Torque components & \\
\hline $\begin{array}{l}\text { Sockets: } \\
\cdot 15 / 16 \text { in., } 12 \text { pt. } \\
\cdot 3 / 4 \text { in., } 12 \text { pt. }\end{array}$ & $\begin{array}{l}\text { Inner vessel lid closure bolts } \\
\text { Port closure bolts }\end{array}$ & \\
\hline $\begin{array}{l}\text { Hex Bit Sockets: } \\
-7 / 8 \text { in., } 6 \text { pt. } \\
-1-1 / 2 \text { in., } 6 \text { pt. (23 in. long minimum) }\end{array}$ & $\begin{array}{l}\text { Outer cask lid closure bolts } \\
\text { Impact limiter bolts }\end{array}$ & \\
\hline Cotter Pin Removal Tool & Removing small O-rings & \\
\hline Utility Knife & Cutting tube for leak testing & \\
\hline Small Flashlight & Inspection of threads and cavities & \\
\hline $\begin{array}{l}\text { Lint-free rags (Wilshire Contamination } \\
\text { Control, 5922 Farnsworth Court, } \\
\text { Carlsbad, CA 92008), (619) 929-6950, } \\
\text { Part Number 5710, Polywipe or } \\
\text { Berkshire, P.O. Box 588, Great } \\
\text { Garrington, MA 012301, Texwipe, } \\
\text { (800) 242-7000 }\end{array}$ & Cleaning & \\
\hline Spray Bottle - (1 quart) & Applying alcohol when cleaning surfaces & \\
\hline Argon & Pressure Cleaning Threads & \\
\hline Helium (welding grade with $\mathrm{C}$ of $\mathrm{C}$ ) & Leak testing & \\
\hline $\begin{array}{l}\text { Vacuum Grease (with halide content } \\
\text { less than } 200 \mathrm{ppm} \text { ) }\end{array}$ & Lubricate O-rings & \\
\hline Alcohol (denatured) & Cleaning surfaces & \\
\hline
\end{tabular}




\section{Table 1.2 Recommended User Supplied Tools, Equipment, and Consumables}

\begin{tabular}{||l|l|c||}
\hline \multicolumn{1}{|c|}{ Item } & \multicolumn{1}{|c||}{ Application } & $\checkmark$ \\
\hline $\begin{array}{l}\text { O-ring: Buna-N, 70 durometer 1-3/4 in. } \\
\text { ID X 1/8 in. W (PN 2-224) and 5/8 in. ID x } \\
1 / 8 \text { in. W (PN 2-208) }\end{array}$ & Test port tools & \\
\hline Nickel Bearing Lubricant & Trailer trunnion bolts & \\
\hline $\begin{array}{l}\text { Keensert Installation Tools (THXHD } \\
\text { 2007L and THD 1409L) }\end{array}$ & Installation of threaded inserts & \\
\hline Rubber Gloves & Cleaning & \\
\hline $\begin{array}{l}\text { Load Stabilizing Jack (McMaster-Carr } \\
\text { \#8817T62 or equivalent) }\end{array}$ & Stabilize free standing trailers & \\
\hline RH Payload Cannister & Contain payload & \\
\hline $\begin{array}{l}\text { Tamper Seals, American Casting and } \\
\text { Manufacturing Corp., 51 Commercial } \\
\text { St., Plainview, NY } 11803 \\
516-349-7010)\end{array}$ & Seal package for shipment & \\
\hline $\begin{array}{l}\text { SS/brass Brushes, flat and 3/4 in., } 7 / 8 \text { in., } \\
1 \text { in., 1-1/8 in., 1- } 1 / 4 \text { in., and 1-3/4 in. }\end{array}$ & Bolt and port thread cleaning & \\
\hline
\end{tabular}


Figure 1.1. RH Packaging

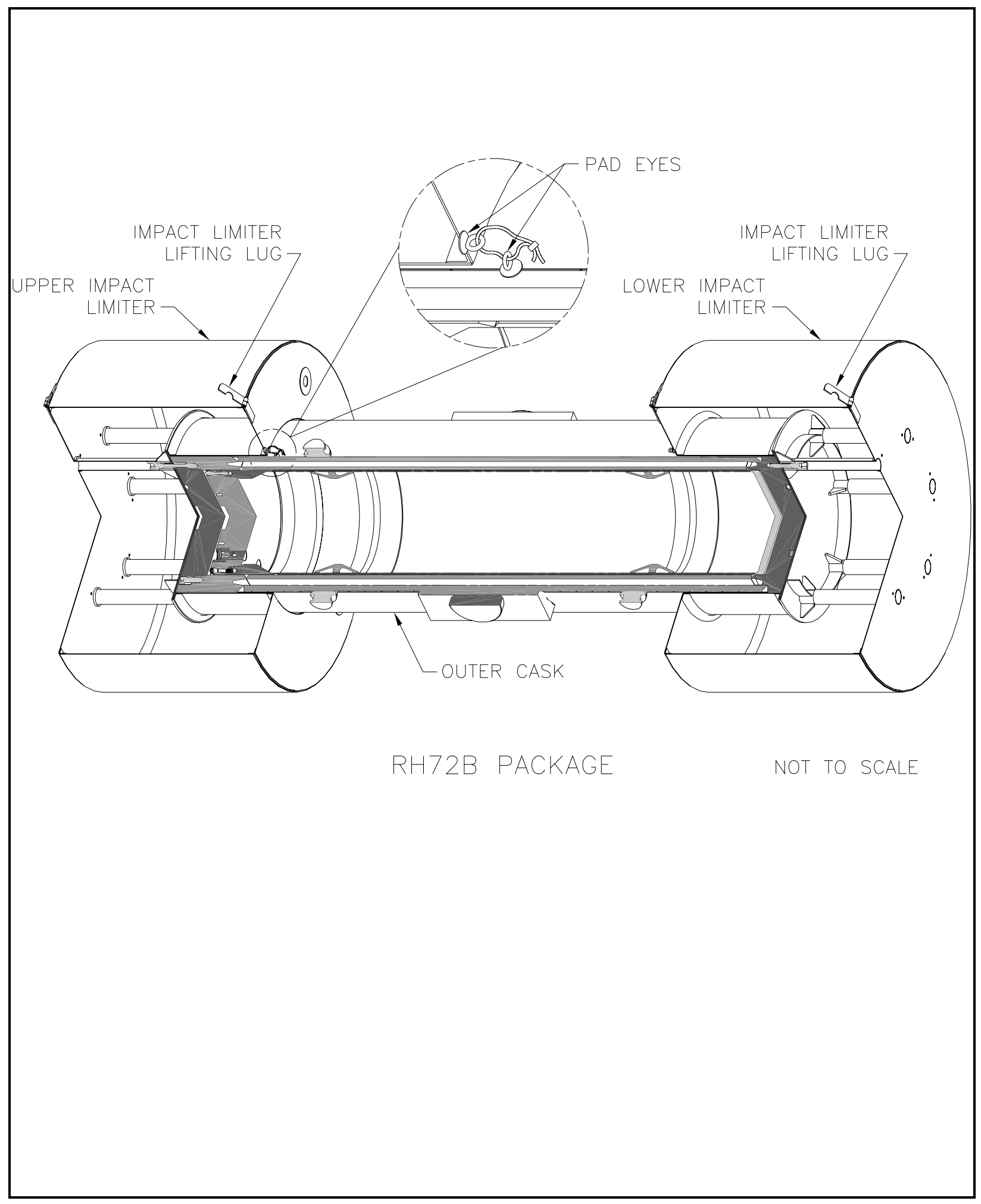




\section{Figure 1.2. RH Packaging Assembly}

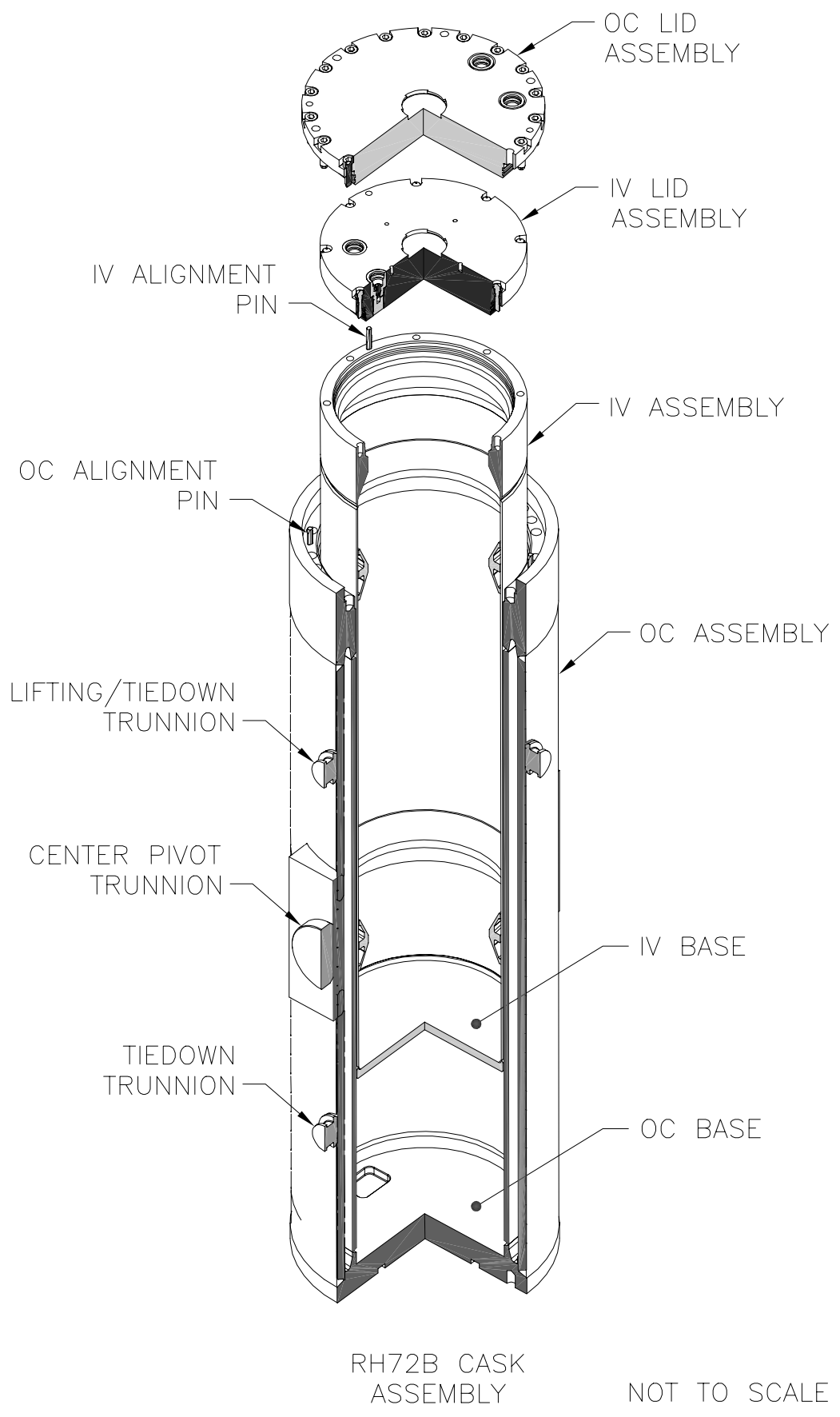


Figure 1.3. Outer Cask Assembly

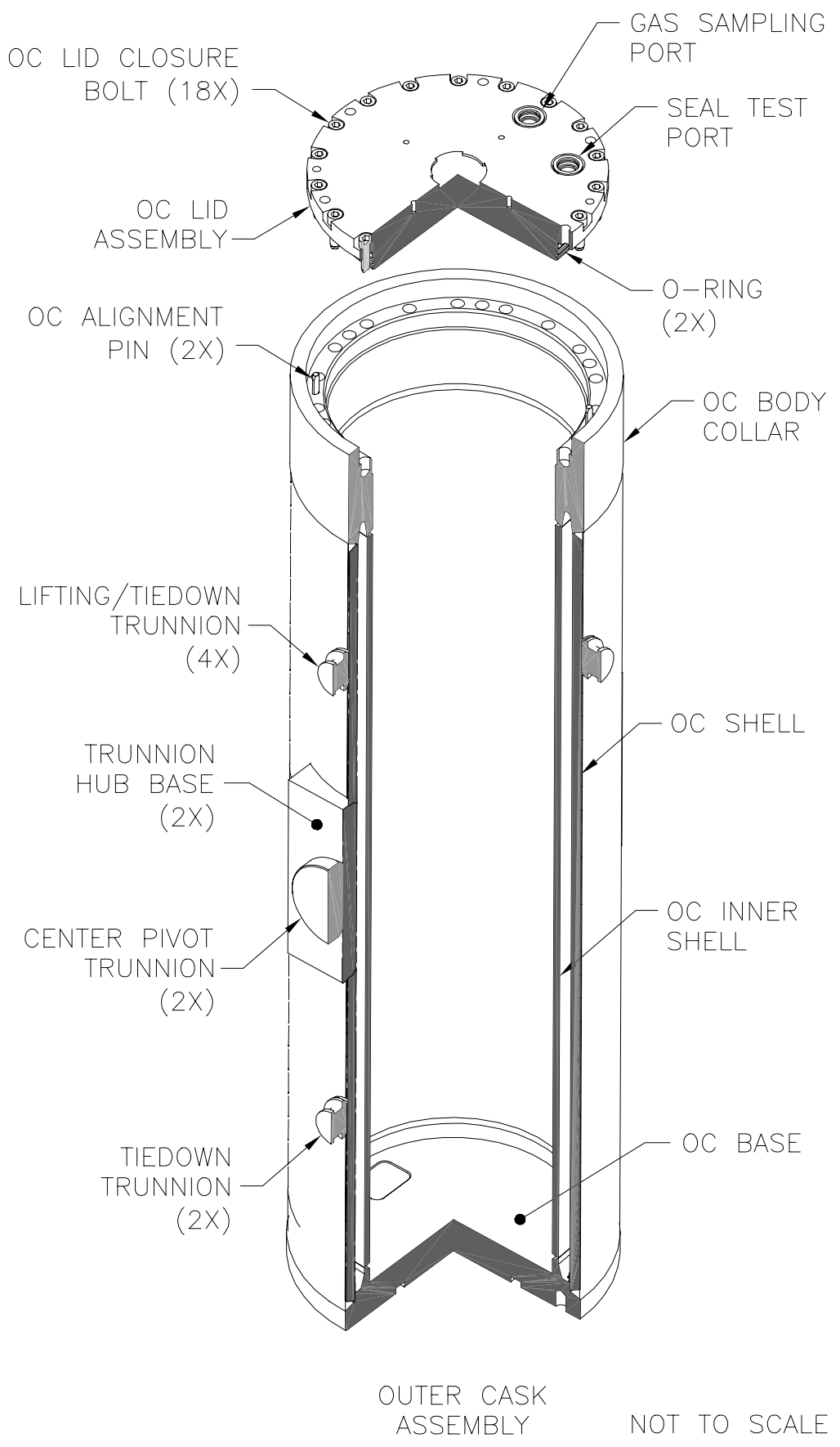


Figure 1.4. Inner Vessel Assembly

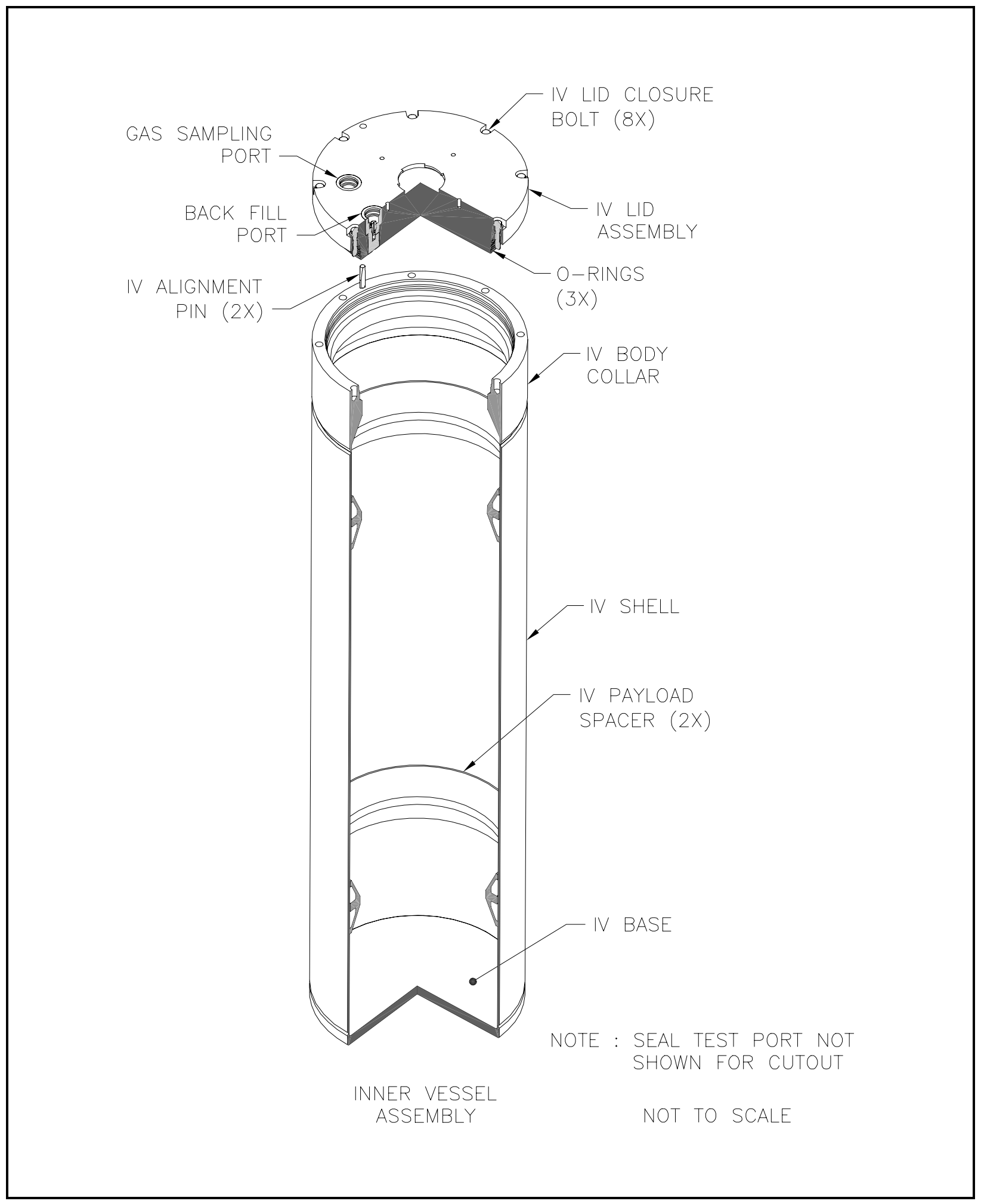


Figure 1.5. Test Port Tool Interface

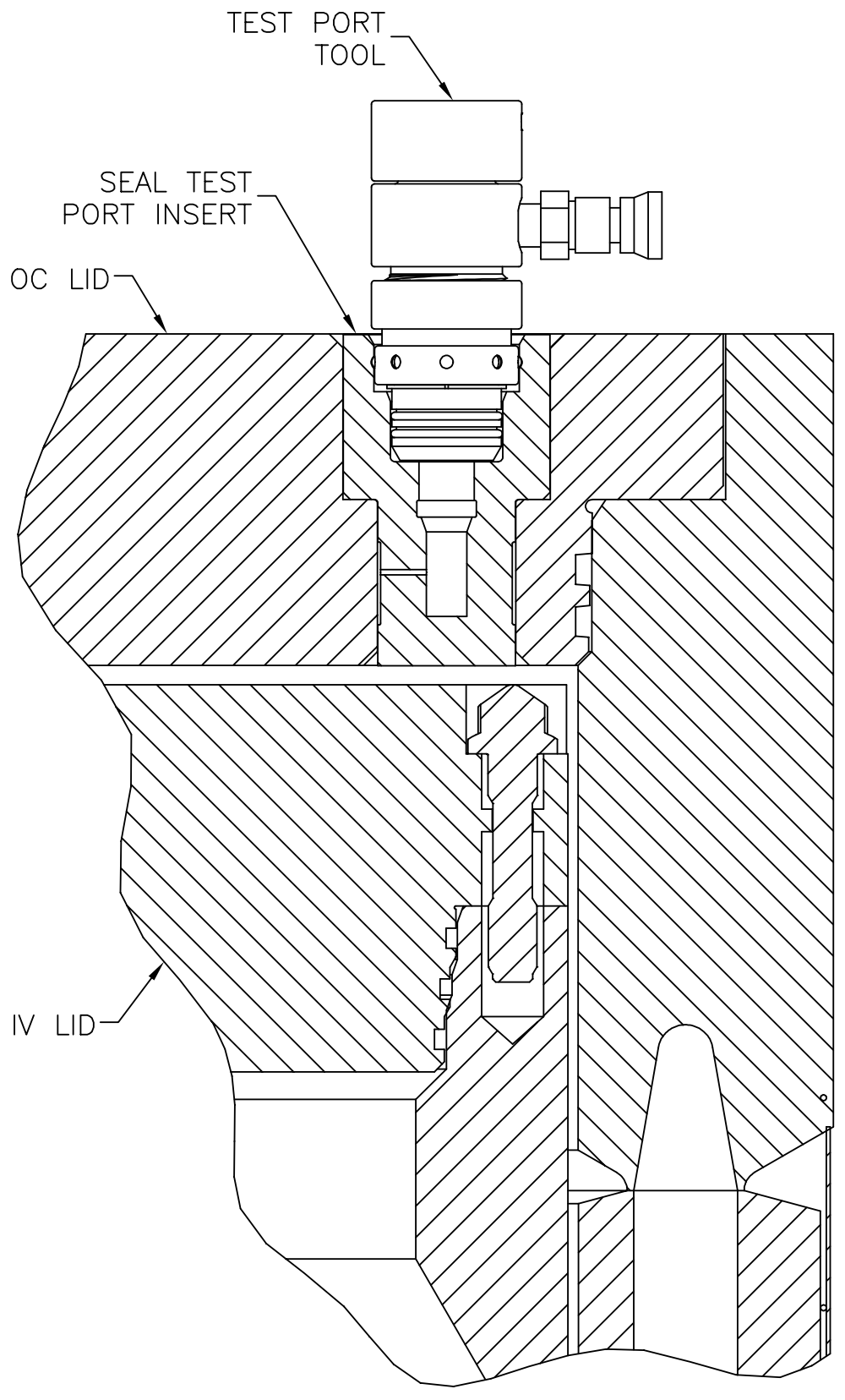

DETAIL 1

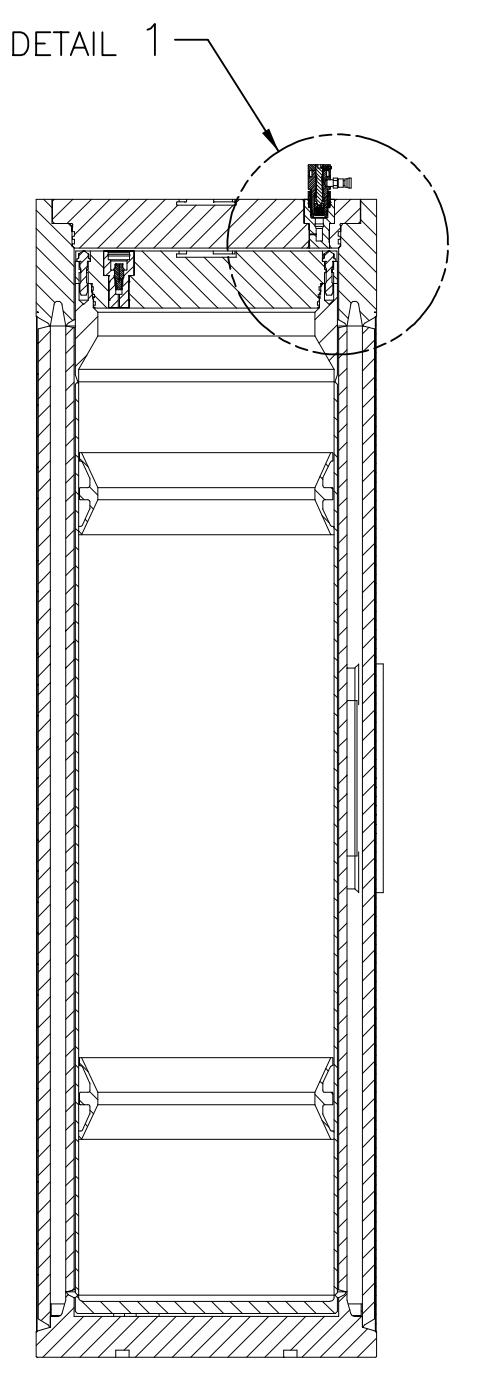

CASK/TOOL INTERFACE

NOT TO SCALE 
Figure 1.6. Test Port Tool (164-F-001) - (P/N 2078-500-01)

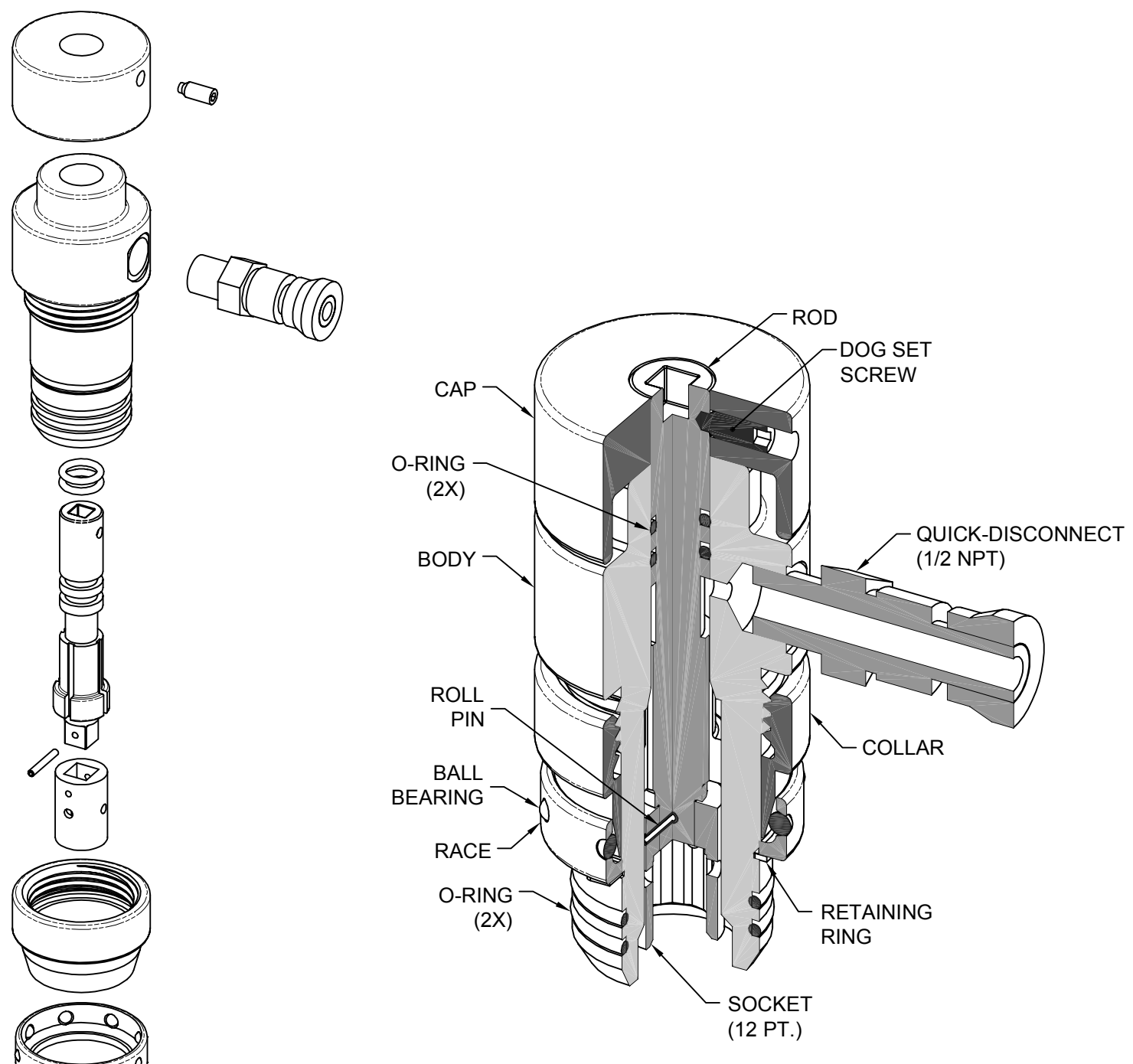

TEST PORT TOOL ASSEMBLY

NOT TO SCALE

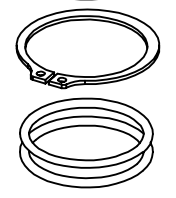

EXPLODED ISOMETRIC VIEW

NOTE : USES O-RINGS: BUNA-N, 70 DUROMETER, PART \#2-208 \& \#2-224. 
Figure 1.7. Impact Limiter Components

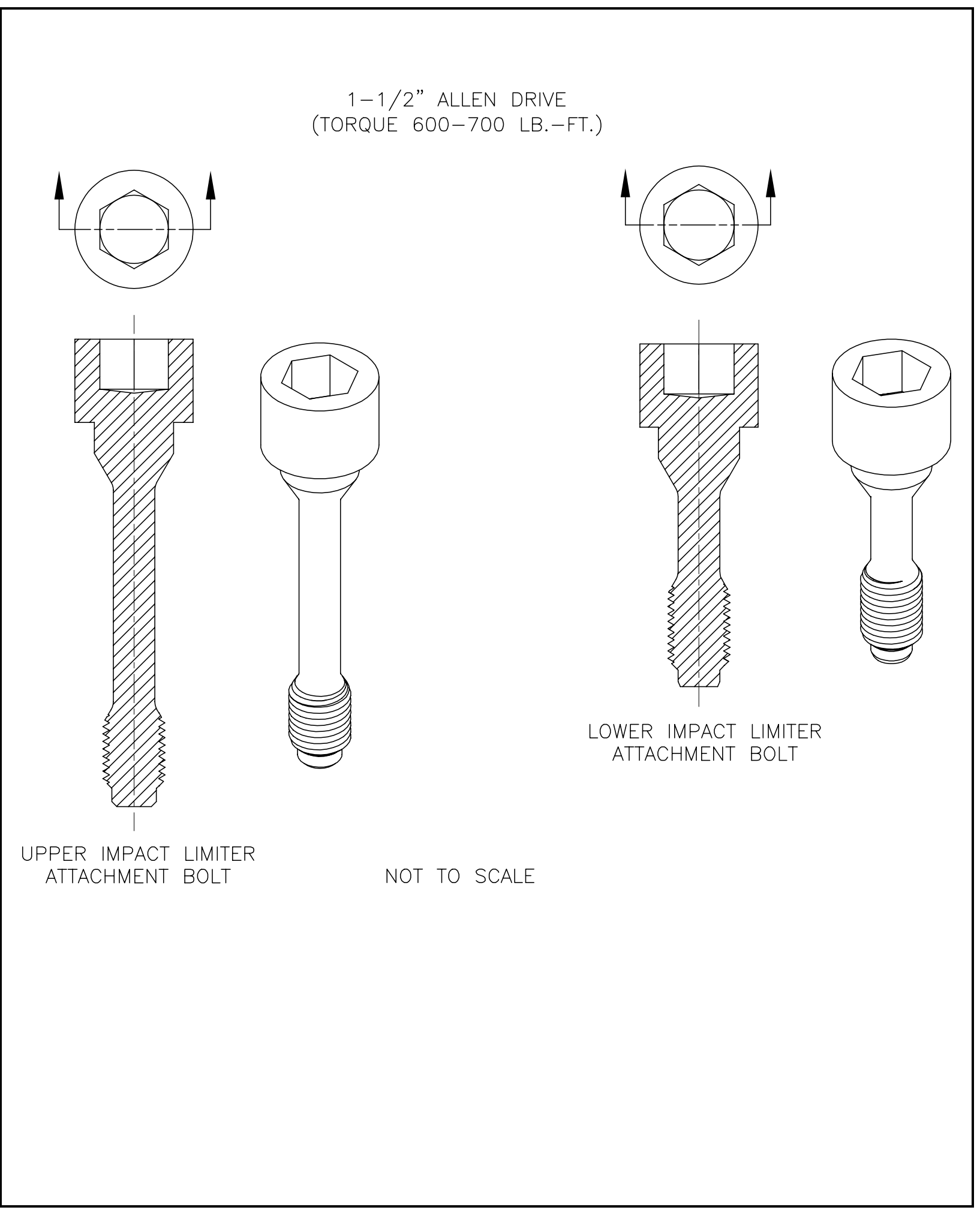




\section{Figure 1.8. Outer Cask Components}

7/8" ALLEN DRIVE

(TORQUE 600-700 LB.-FT.)
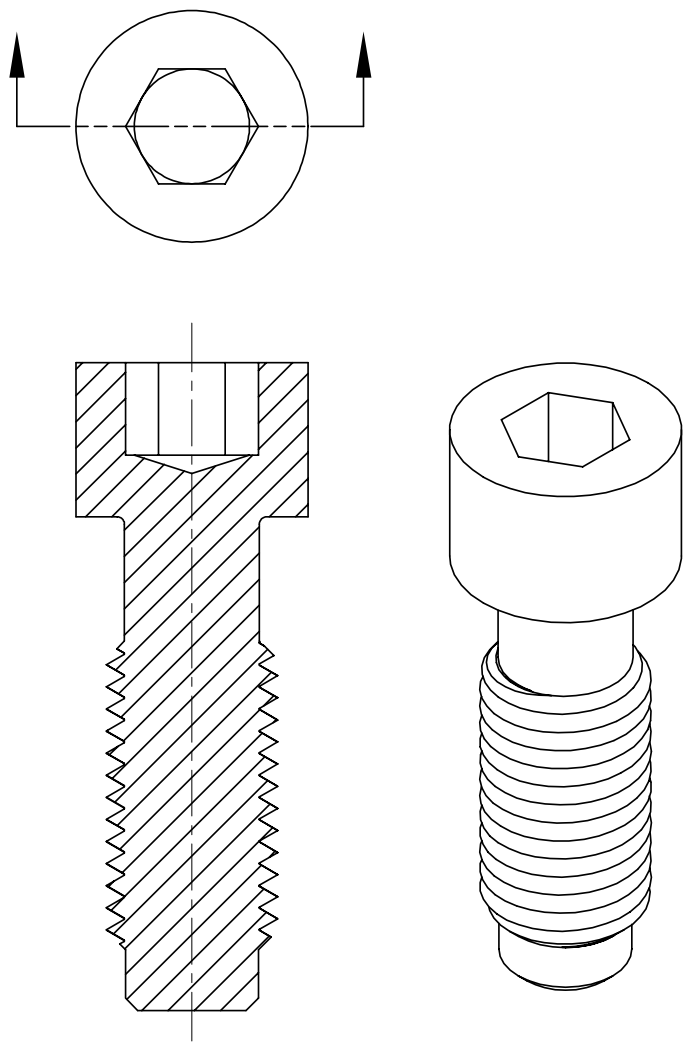

OC LID

CLOSURE BOLT

$$
\begin{aligned}
& \text { 3/4" - 12PT. SOCKET } \\
& \text { (TORQUE 15-20 LB.-FT.) }
\end{aligned}
$$
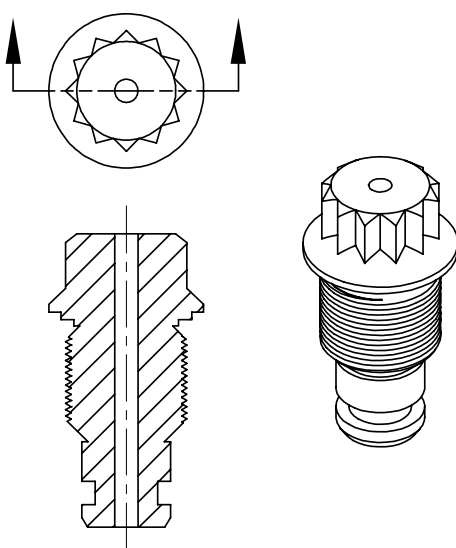

PORT CLOSURE BOLT

NOTE : USES O-RING : BUTYL PER RR0405-70, AS-568-206

NOT TO SCALE 
Figure 1.9. Inner Vessel Components

3/4" - 12 PT. SOCKET

(TORQUE 15-20 LB.-FT.)
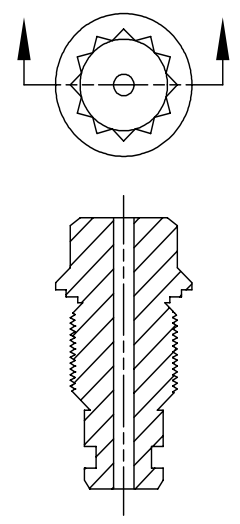

PORT CLOSURE BOLT

NOTE : USES O-RING : BUTYL PER RR0405-70, AS-568-206

\begin{abstract}
15/16" - 12 PT. SOCKET (TORQUE 100-200 LB.-FT.)
\end{abstract}
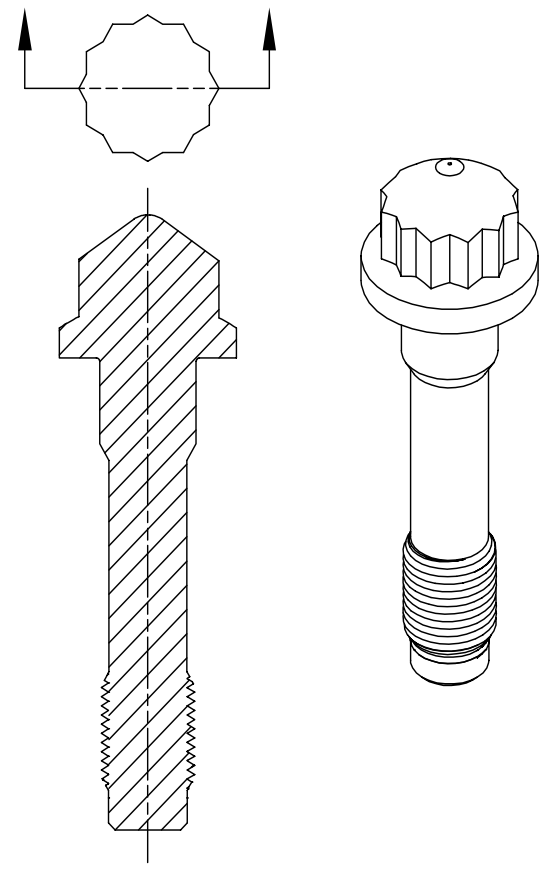

IV LID
3/4" - 12 PT. SOCKET

(TORQUE 15-20 LB.-FT.)
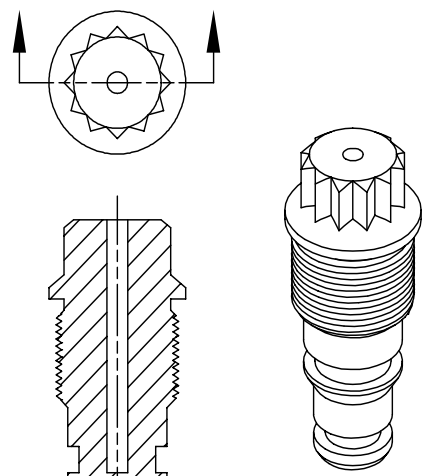

\section{CLOSURE BOLT}

NOTE : USES O-RING : BUTYL PER RR0405-70, AS-568-206 AND AS-568-209 
Figure 1.10. Outer Lid Tool Assembly - (2078-500-02)

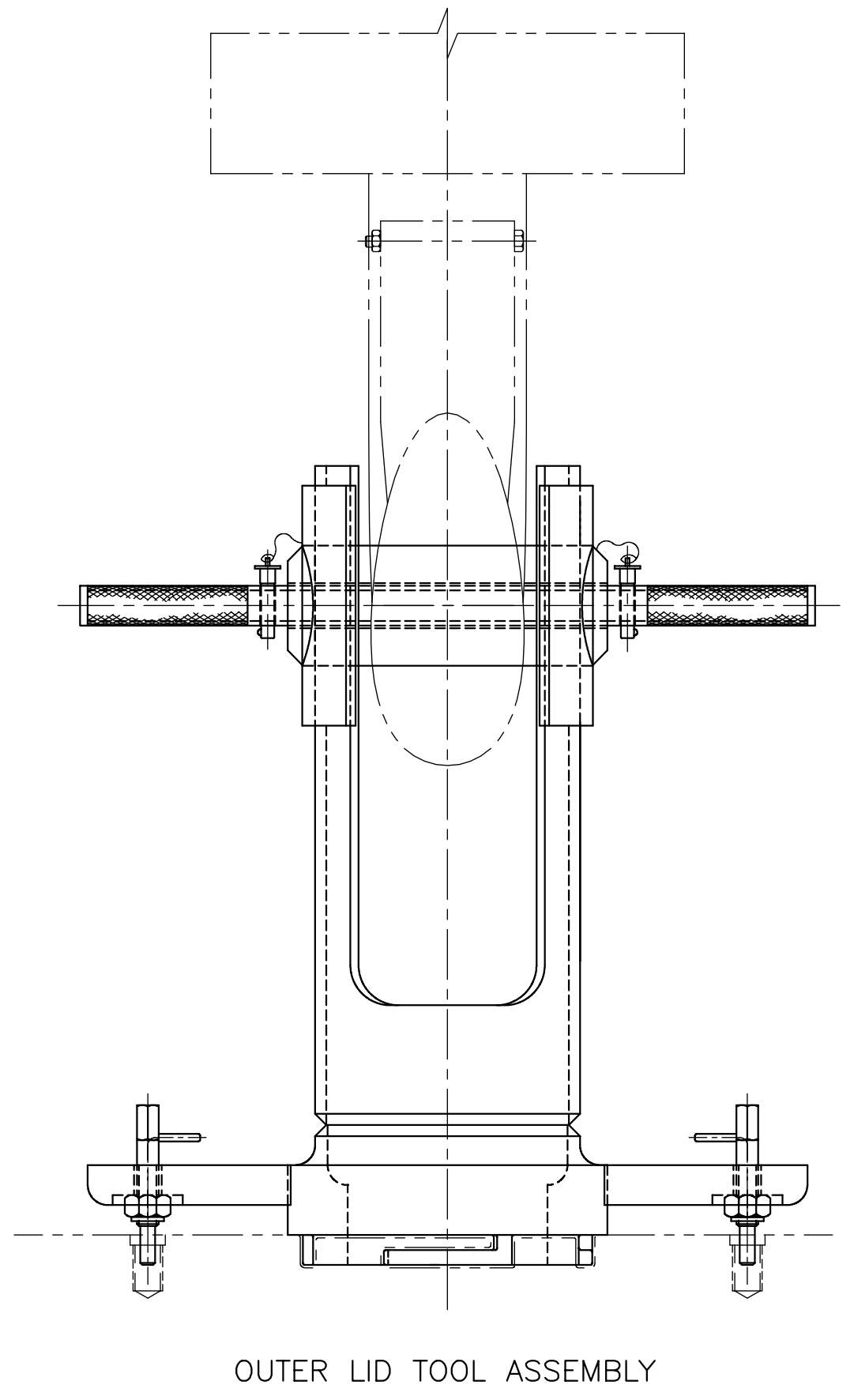


Figure 1.11. Inner Lid Tool Assembly - (2078-500-03)

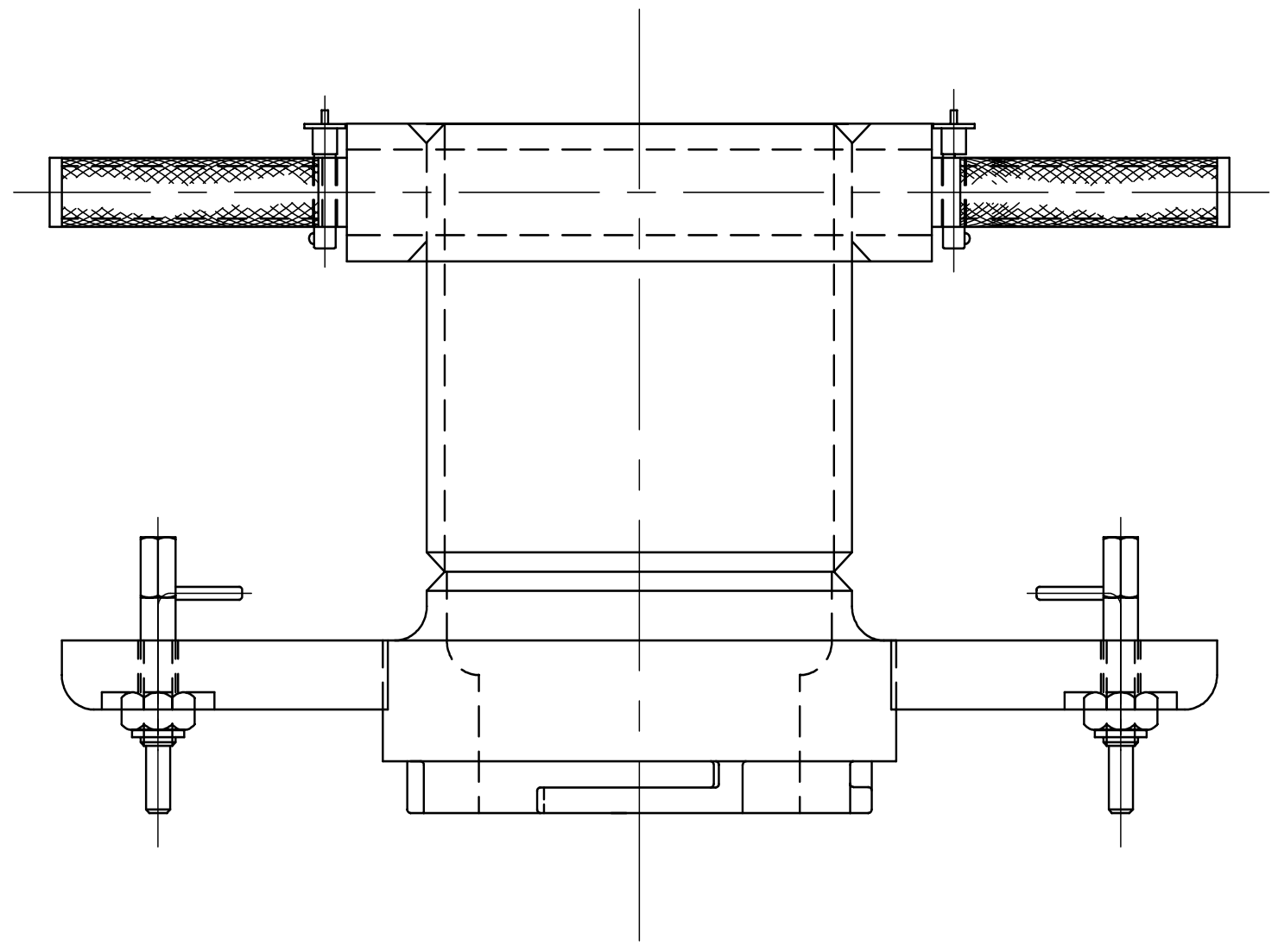

INNER LID TOOL ASSEMBLY 
Rev. 0

Page 29 of 55

Figure 1.12. Lifting Yoke - (2078-500-04)
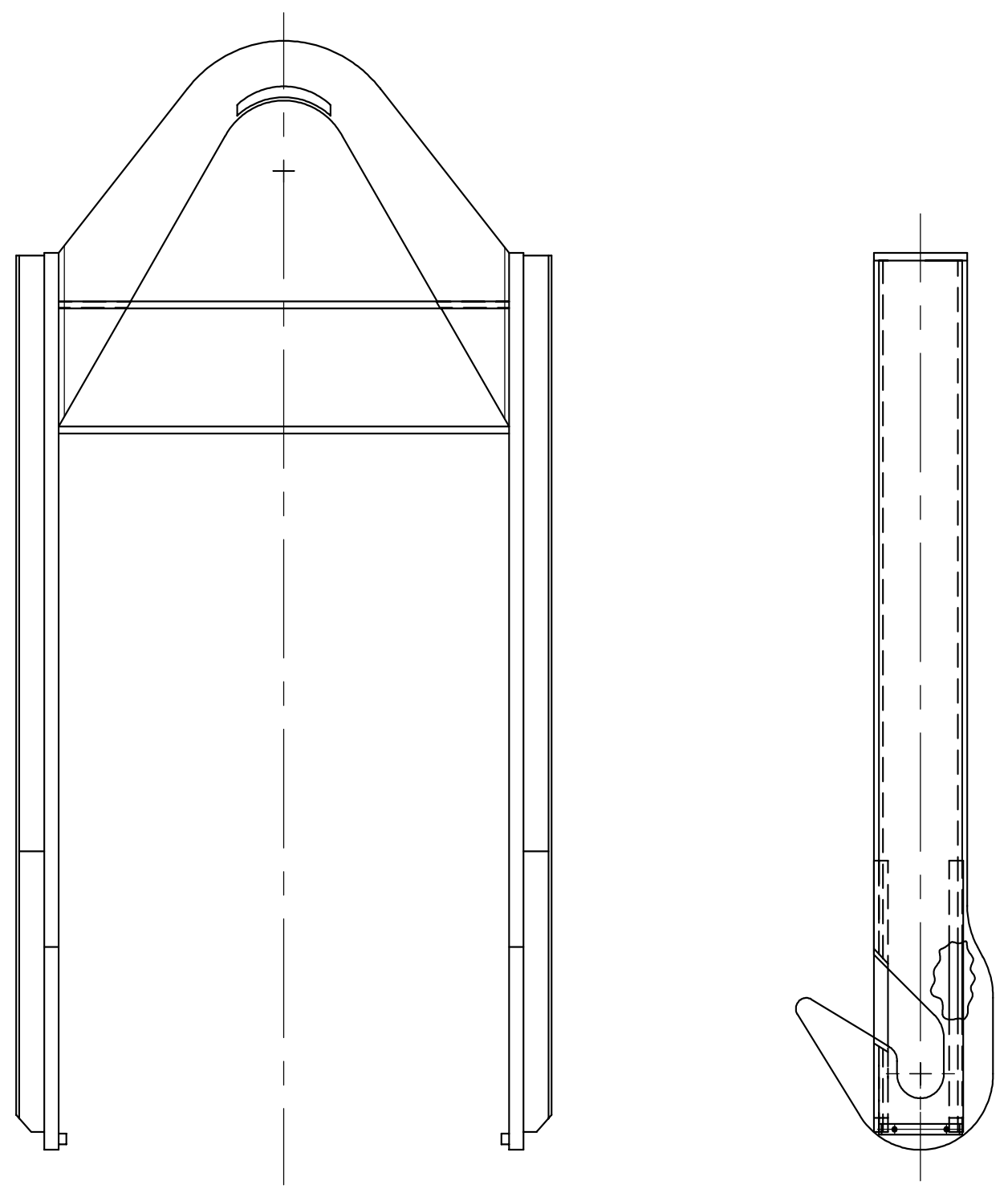

LIFTING YOKE 


\subsection{Spare Parts/Bench Stock}

Table 1.3, Spare Parts (Bench Stock), lists the spare parts that support replacement of packaging components during routine operations. Levels of supply are based on historical data relating to the frequency of usage of packaging and are expressed as the quantity of parts that should be on hand with minimum/maximum levels to be stocked. A bench stock inventory should be conducted quarterly to determine shortages. Replacements will be provided through the WIPP M\&O Contractor RH Packaging Maintenance Engineer. The on-hand, P.O. No., and needed columns may be used to conduct inventories and should be faxed to the WIPP M\&O Contractor RH Packaging Maintenance Engineer quarterly (at the end of March, June, September and December) for parts replacement. There may be several different PO numbers associated with a given part.

Table 1.3 Spare Parts (Bench Stock)

\begin{tabular}{||l|c|c|c|c|c||}
\hline \hline \multicolumn{1}{|c|}{ Description } & $\begin{array}{c}\text { Part No.I } \\
\text { Substitute }\end{array}$ & $\begin{array}{c}\text { P.O. } \\
\text { No. }\end{array}$ & $\begin{array}{c}\text { Min/ } \\
\text { Max }\end{array}$ & $\begin{array}{c}\text { On } \\
\text { Hand }\end{array}$ & Needed \\
\hline \hline $\begin{array}{l}\text { IV Gas Sampling Port Closure Bolt Upper } \\
\text { O-ring Seal }\end{array}$ & $200-01$ & & $1-10$ & & \\
\hline \begin{tabular}{|l|l|l||} 
IV Gas Sampling Port Closure Bolt Lower \\
O-ring
\end{tabular} & $200-02$ & & $1-10$ & & \\
\hline IV Backfill Port Closure Bolt O-ring Seal & $200-03$ & & $1-10$ & & \\
\hline IV Seal Test Port Closure Bolt O-ring & $200-04$ & & $1-10$ & & \\
\hline IV Lid Inner O-ring & $200-05$ & & $1-10$ & & \\
\hline IV Lid Middle O-ring Seal & $200-06$ & & $1-10$ & & \\
\hline IV Lid Outer O-ring & $200-07$ & & $1-10$ & & \\
\hline IV Gas Sampling Port Closure Bolt & $200-10$ & & $1-3$ & & \\
\hline IV Backfill Port Closure Bolt & $200-11$ & & $1-3$ & & \\
\hline IV Seal Test Port Closure Bolt & $200-12$ & & $1-3$ & & \\
\hline IV Lid Closure Bolt & $200-13$ & & $1-3$ & & \\
\hline IV Lid Closure Bolt Spring & $200-14$ & & $1-3$ & & \\
\hline IV Lid Closure Bolt Threaded Insert & $200-15$ & & $1-3$ & & \\
\hline IV Backfill Port Insert & $200-16$ & & $1-3$ & & \\
\hline IV Gas Sampling Port Insert & $200-17$ & & $1-3$ & & \\
\hline IV Seal Test Port Insert & $200-18$ & & $1-3$ & & \\
\hline IV Alignment Pin & $200-19$ & & $1-3$ & & \\
\hline $\begin{array}{l}\text { IV Lid Closure Bolt Washer, 7/16 in. (1/2 in. } \\
\text { ID X 1-1/8 in. OD) Stainless Steel }\end{array}$ & $200-20$ & & $1-3$ & & \\
\hline OC Gas Sampling Port Closure Bolt & $300-01$ & & $1-10$ & & \\
\hline O-ring Seal & $300-02$ & & $1-10$ & & \\
\hline OC Seal Test Port Closure Bolt O-ring & $300-03$ & & $1-10$ & & \\
\hline OC Lid Inner Main O-ring Seal & $300-04$ & & $1-10$ & & \\
\hline OC Lid Outer Main O-ring & & & \\
\hline
\end{tabular}


Table 1.3 Spare Parts (Bench Stock)

\begin{tabular}{||l|c|c|c|c|c||}
\hline \hline \multicolumn{1}{|c|}{ Description } & $\begin{array}{c}\text { Part No.I } \\
\text { Substitute }\end{array}$ & $\begin{array}{c}\text { P.O. } \\
\text { No. }\end{array}$ & $\begin{array}{c}\text { Min/ } \\
\text { Max }\end{array}$ & $\begin{array}{c}\text { On } \\
\text { Hand }\end{array}$ & Needed \\
\hline \hline OC Gas Sampling Port Closure Bolt & $300-10$ & & $1-3$ & & \\
\hline OC Seal Test Port Closure Bolt & $300-11$ & & $1-3$ & & \\
\hline OC Lid Closure Bolt & $300-12$ & & $1-3$ & & \\
\hline OC Lid Closure Bolt Threaded Insert & $300-13$ & & $1-3$ & & \\
\hline OC Seal Test Port Insert & $300-14$ & & $1-3$ & & \\
\hline OC Gas Sampling Port Insert & $300-15$ & & $1-3$ & & \\
\hline OC Alignment Pin & $300-16$ & & $1-3$ & & \\
\hline Upper Impact Limiter Attachment Bolt & $400-10$ & & $1-3$ & & \\
\hline Lower Impact Limiter Attachment Bolt & $400-11$ & & $1-3$ & & \\
\hline $\begin{array}{l}\text { Impact Limiter Attachment Bolt Threaded } \\
\text { Insert, 1-1/4 in. - 7UNC X 1-3/4 in. - 12UNC } \\
\text { X 2 in. long) }\end{array}$ & $400-13$ & & $1-3$ & & \\
\hline $\begin{array}{l}\text { Pad Eye, 5/8 in. eye ID, McMaster } \\
\text { Carr Cat 101 }\end{array}$ & $400-14$ & & $1-3$ & & \\
\hline $\begin{array}{l}\text { Plastic Pipe Plugs, 1-1/2 in. NPT, hex } \\
\text { socket, plastic }\end{array}$ & $400-15$ & & $1-3$ & & \\
\hline $\begin{array}{l}\text { Impact Limiter Lift Lug Assembly 4 in. } \\
\text { wide X 12 in. long 1/4 in. stock Type 304 } \\
\text { stainless steel fabricated hinge assembly }\end{array}$ & $400-16$ & & $1-3$ & & \\
\hline \hline
\end{tabular}

\subsection{Transport Trailer}

The $\mathrm{RH}$ transport trailer is designed for transportation of the empty $\mathrm{RH}$ packaging and loaded $\mathrm{RH}$ packages. Air-ride suspension trailers are designed with a goose neck equipped with a standard kingpin arrangement. Each trailer is equipped with trunnion cap devices used for securing packages to the trailer. 


\subsection{GENERAL REQUIREMENTS}

\subsection{Records Maintenance}

Packaging users must comply with 10 CFR Part 71.91, "Records." Records regarding inspections, tests, and maintenance must be retained for three years after the life of the package to which they apply. Records relating to each shipment must be maintained for three years after the shipment.

All records of maintenance activities performed on the packaging will be maintained by the WIPP M\&O contractor. Records are designated as QA records and will be maintained as permanent records. All records concerning design, fabrication, and assembly, results of reviews, inspections, tests, and audits; results of monitoring work performance and materials analyses; and results of maintenance, modification and repair activities must be retained for three years after the life of the packaging to which they apply. Inspection, test, and audit records must identify the inspector or data recorder, the type of observation, the results, the acceptability and the action taken concerning any deficiencies noted.

\subsection{Document Distribution}

Upon completion, original maintenance records and copies of supporting documentation shall be transmitted to the WIPP M\&O Contractor RH Packaging Maintenance Engineer, P.O. Box 2078, mailstop GSA-211, Carlsbad, NM 88221 within seven working days of performance of maintenance. The maintenance records will become part of the permanent $\mathrm{RH}$ packaging system record. A copy should be faxed or e-mailed immediately upon use to the M\&O Contractor RH Packaging Maintenance Engineer at (505) 234-7055.

Users preparing maintenance records should retain copies for their files.

The work instructions should be used as a checklist by those performing the work. Data attachments to the work instructions must be transmitted to WIPP with the original $\mathrm{RH}$ packaging maintenance record, unless stated otherwise in the work instruction.

\subsection{Approved Work/Periodic Maintenance Instructions}

Approved work and periodic maintenance instructions are listed in Attachment B, Approved Work Instructions. Completed originals will be filed with and become part of the permanent record. For approved work instructions intended for one-time use (either the WIPP M\&O contractor or vendor-generated), the original will become part of the permanent record.

\subsection{Material Control}

All initial and replacement components of the packaging are procured by the WIPP $\mathrm{M} \& \mathrm{O}$ contractor and shall be verified as complying with applicable material requirements as specified in SARP drawings. Inspection reports, certified material test reports, and material certificates of conformance shall be maintained by the WIPP M\&O contractor. 
Spare parts will be furnished to user sites by the WIPP M\&O contractor. The parts package will be labeled (or have a detachable label inside the package) with part number, description, WIPP purchase order (PO) number, and shelf life expiration, if applicable. Users will segregate and store parts by part number. Site bench stock should be maintained at the levels shown in Table 1.3.

All replaced (used) components should be disposed of following site procedures. If return of used components is deemed necessary for analysis, usage trends, or investigation, a formal request for return will be issued to user sites.

\subsection{Quality Assurance Requirements}

A QA system, meeting controlling functions of the applicable 18 criteria of 10 CFR Part 71, Subpart H, "Quality Assurance," shall be implemented at the loading and unloading facilities as defined by DOE Order 460.2, Departmental Materials Transportation and Packaging Management. Annex 2 of the NRC Regulatory Guide 7.10 shall be used as a guideline. These requirements also apply to maintenance, repair, replacement and/or modifications, as approved by the owner.

Existing QA programs may be used to satisfy the above requirements, provided a review has been made as to their applicability to the scope of activities performed by each participant and equivalency of the program to the NRC's QA program requirements in Subpart $\mathrm{H}$. It is the responsibility of the involved participant to obtain approval of their QA program from the appropriate DOE Field Office.

Before loading a cask with radioactive waste, an audit or surveillance will be conducted by CBFO and the site shall be certified to use the cask.

\subsection{Training Requirements}

Users shall have the responsibility for a training program specific to this work scope to ensure that qualified personnel experienced in their assigned tasks satisfactorily perform maintenance, nondestructive testing, leak testing, component replacement and related operations. To ensure uniformity of training, Attachment $\mathrm{C}, \mathrm{RH}$ Packaging Qualification Requirements, is included and provides the minimum requirements that must be included in site qualification cards for those sites which use the packaging. Users may supplement these requirements as appropriate.

All initial SME's for the 72-B cask must be evaluated by the WIPP M\&O Contractor RH Packaging Maintenance Engineer and signed off to the knowledge of an SME before training others on 72-B cask knowledge.

Leak test personnel shall meet the requirements of the American Society of Nondestructive Testing (ASNT) Recommended Practice No. SNT-TC-1A.

\subsection{Maximum Packaging Weights}

The WIPP Waste Information System (WWIS) Packaging Reference Data Table may be used to obtain packaging weights. 
The maximum gross shipping weight of an $\mathrm{RH}-\mathrm{TRU}$ 72-B shipping package is $45,000 \mathrm{lb}$.

\subsection{Shipping Requirements}

When shipping empty packaging to WIPP, sites will fax a copy of the radiation and contamination survey and survey map (internal [if opened] and external) performed when the packaging was last closed to the WIPP M\&O contractor Radiological Control at (505) $234-8963$, or 234-6030 (Shipping Coordination), before departure.

\subsection{Shipment Scheduling}

Package shipments are coordinated by the WIPP M\&O Contractor Shipping Coordination. Once agreed upon by the shipping site traffic manager and the representative, the generator site will enter the advance shipment schedule into the DOE Transportation Tracking and Communication System (TRANSCOM) satellitebased shipment tracking system. Based on this schedule, the shipper is responsible for entering the bill of lading into TRANSCOM at least 24 hours before shipment. Before departure of the shipment, the shipper is required to change the Designated User in the TRANSCOM bill of lading to that of the WIPP Central Monitoring Room.

In addition, only shipments approved in the WWIS shall be accepted for transport to WIPP.

\subsection{Nonconformance Reports}

Conditions encountered during inspection of the packaging that are not correctable by using the work instructions in Attachment B should be reported to the WIPP M\&O Contractor RH Packaging Engineer for resolution. NCRs shall be resolved before shipment. Discrepant conditions not corrected by the packaging user shall be entered into the Computerized History and Maintenance Planning System (CHAMPS) in the Deferred Maintenance module. Deferred maintenance tasks will be performed during periodic maintenance or on an as needed basis.

\subsection{PAYLOAD PREPARATION}

DOE/WIPP 02-3284, RH Packaging Operations Manual, for the payload assembly is available on the internet at: http://www.wipp.ws/library/t2omi/t2omi.htm. Users are responsible for ensuring they are using the current revision and change notice.

\subsection{PACKAGE OPERATING INSTRUCTIONS}

DOE/WIPP 02-3284, RH Packaging Operations Manual, is available on the internet at: http://www.wipp.ws/library/t2omi/t2omi.htm. Users are responsible for ensuring they are using the current revision and change notice.

\subsection{PACKAGE MAINTENANCE INSTRUCTIONS}

This section describes the maintenance program used to ensure continued performance of the packaging (see Section 1.3, Definitions for annual and five-year maintenance). The annual maintenance tests and inspections described in this section 
shall be performed within 12 months before each shipment. Annual maintenance tests and inspections need not be performed for out-of-service packages.

All maintenance, repairs performed, or components replaced will be documented using a Maintenance Record. Information regarding preparation of the Maintenance Record is outlined in Section 5.4, Maintenance Records. Records shall be maintained by the WIPP M\&O contractor to document completion of the maintenance schedule.

If a deficiency is found which is not covered by this document, or which is beyond the repair capability of the discovering site, that site will follow its approved procedure for reporting deficiencies and contact the RH Packaging Maintenance Engineer within 24 hours for disposition. All questions regarding the continued integrity of packagings shall be addressed, in writing, to the WIPP M\&O Contractor Transportation Program, P.O. Box 2078, Carlsbad, NM 88221.

Pre-approved work instructions are listed and linked in Attachment B. Maintenance activities not within the scope of pre-approved work instructions shall be performed using procedures reviewed and approved by the WIPP M\&O Contractor RH Packaging Maintenance Engineer before use. Recommendations for new work instructions or modifications to existing work instructions shall be forwarded in writing to the WIPP M\&O RH Packaging Maintenance Engineer.

Scheduled and unscheduled maintenance will be coordinated by the WIPP M\&O Contractor Transportation Project. Maintenance will be scheduled to maximize the availability of packaging.

NOTE: Section 5.1, Annual Visual Inspections. These inspections are normally done at WIPP or by a WIPP M\&O contractor's subcontracted vendor. Work instructions for annual and five-year maintenance inspections should be used as a checklist when performing these inspections.

Structural, fabrication and maintenance leakage rate test procedures are found in DOE/WIPP 02-3285, RH Packaging Maintenance Manual, at the following link: http://www.wipp.ws/library/t2omi/t2omi.htm.

\subsection{Annual Visual Inspections}

Table 5.1, Annual Visual Inspections, Acceptance Criteria and Corrective Action, defines the annual visual inspections to be performed on the IV and OC. General cleanliness should be observed for all components. Cloths or towels and denatured alcohol should be used to clean components to enable proper visual inspection of the components. Visual inspections shall determine that surfaces are free of excessive deformation and that all threaded components are as specified and in good operating condition.

\subsubsection{Annual Component Inspections}

Table 5.2, Annual Component Inspection, Acceptance Criteria and Corrective Action, denotes the annual dimensional inspections to be performed. General cleanliness should be observed for all components. Use cloths or towels and denatured alcohol to clean components to enable proper dimensional inspection. Should components fail to 
meet the defined acceptance criteria following corrective action(s), prepare an NCR for disposition. All NCRs shall be dispositioned by the WIPP M\&O contractor.

\subsubsection{Annual IV Interior Surfaces Inspection}

An annual inspection shall be performed on the interior welds and accessible internal base metal surfaces of the IV. The inspections shall be performed by visual inspection. The visual inspection shall be for surface corrosion. If an abnormality is found during visual inspection then a liquid penetrant inspection will be performed. If surface corrosion indications are found, locations will be recorded, a photographic record made, and an Approval Request/Variation Request (AR/VR) submitted for disposition by the WIPP M\&O Contractor RH Packaging Maintenance Engineer.

Following the IV interior surfaces visual inspection, all welds and base metal shall be visually inspected for plastic deformation or cracking. If indications are found then a liquid penetrant inspection must be performed per ASME Boiler and Pressure Vessel Code, Section V, Article 6, and ASME Boiler and Pressure Vessel Code, Section III, Division 1, Subsection NB, Articles NB-2500 and NB-5000. Indications of cracking shall be recorded on a nonconformance report and dispositioned before corrective actions. Relevant indications shall be repaired following applicable work instructions.

\subsection{Five-Year Inspections}

Five-year inspections shall consist of all of the annual inspection requirements, liquid penetrant inspections of all interior and exterior base material and pressure retaining welds, and threaded component replacement following Work Instruction RH.08.

\subsubsection{Five Year Structural Test}

At a maximum five-year interval, inspections shall be performed on the accessible exterior base material, OC interior, and IV interior and exterior surfaces for evidence of chemically induced stress corrosion. This shall consist of a liquid penetrant inspection of all surfaces. This includes accessible shell, head, flange and weld surfaces per ASME Boiler and Pressure Vessel Code, Section V, Article 6; and Section III, Division 1 , Subsection NB, Article NB-5000.

Upon successful completion of the preceding tests, periodic leakage rate testing shall be performed.

\subsubsection{Structural Pressure Test}

There is no requirement for an annual or five-year structural pressure test. Structural pressure tests shall be completed on 72-B casks after completion of a weld repair to a containment structure. The OC and IV shall be pressure tested to 150 percent of the maximum normal operating pressure to verify structural integrity. The maximum normal operating pressure of the OC and IV is 150 psig; therefore, the OC and IV shall be pressure tested to $225 \mathrm{psig}$. Upon completion of the pressure test, the OC interior, IV interior and exterior base material and pressure retaining welds shall be visually inspected for plastic deformation or cracking and shall be examined by liquid penetrant examination method according to Section V Article 6; and Section III, Division 1, Subsection NB, Articles NB-2500 and NB-5000, of ASME Boiler Pressure Vessel Code. 
Indications of cracking or distortion shall be recorded on an NCR for disposition by the WIPP M\&O Contractor RH Packaging Maintenance Engineer.

Upon successful completion of the preceding tests, periodic leakage rate testing shall be performed.

\subsection{Packaging Component Replacement Schedule}

Packaging components shall be replaced as defined in the schedule provided in Table 5.3, Component Replacement Schedule and Work Instruction, or when damage is noted. Should replacement of a given component fail to meet the acceptance criteria, an NCR shall be prepared for disposition by the WIPP M\&O contractor.

\subsection{Maintenance Records}

All maintenance performed on $\mathrm{RH}$ packaging shall be thoroughly and completely documented on a Maintenance Record (Figure 5.1, Maintenance Record).

\subsubsection{Instructions for Completing the Maintenance Record}

- $\quad$ Packaging $\mathrm{S} / \mathrm{N}$ - Record the serial number of the packaging (Example: 00-02).

- Date Initiated - Enter the date that the maintenance was initiated. (If no corrective actions are performed immediately, enter the date the discrepancy was discovered.)

- Location/Site - Enter the acronym for the site or location initiating the maintenance. (Example: INEEL, WIPP, or EPD, etc.)

- Job No. - Enter the next sequential job number from the site packaging maintenance log. (See Section 5.5, Maintenance Log.)

- Reason for Maintenance - Check the appropriate block. Check other for unscheduled inspections, modification, or repairs that are not listed in Attachment B.

- Discrepancy Description - Provide a short narrative description of repair or other discrepancies. No entry is required specifically for annual or five-year maintenance, but list discrepancies discovered as part of these scheduled inspections. List NCR numbers, tag numbers, or correspondence letter numbers, if applicable.

- Work Performed - Provide a concise description of the actions taken to correct discrepancies listed in the Discrepancy Description block. (Example: Replaced IV lid containment O-ring.)

- Work Instructions Used - List the work instruction numbers (e.g., WI-RH.01, WI-RH.02, etc.) used to perform the maintenance covered by the maintenance record.

- $\quad$ Measuring and Test Equipment (M\&TE) Used - List the M\&TE description, serial number (SN), calibration due date and work instruction used. 
- $\quad$ Spare Parts Used - List any spare parts used by description, part number and WIPP PO number. (Required information is printed on packages or available on a removable label provided in the package. Place label in space provided.)

- Work Inspected By - Should be signed and dated by the supervisor of the personnel who performed the work. The signature verifies that the actions taken were within the scope of the work instruction or traveler (if applicable) and the packaging can be returned to service. This signature also shows that the maintenance record is accurate and complete (i.e., all applicable supporting documentation is attached).

- $\quad$ Attach any CMTR's or other reports for materials used.

\subsubsection{Maintenance Record Disposition}

Upon completion, the ORIGINAL RH packaging maintenance record, including original attachments to the work instructions, shall be transmitted within seven working days to: WIPP M\&O Contractor RH Packaging Maintenance Engineer, P.O. Box 2078, Carlsbad, NM 88221. Each record should be placed in numerical order for shipment to the WIPP M\&O Contractor RH Packaging Maintenance Engineer.

\subsection{Maintenance Log}

Each user site shall maintain a packaging maintenance log. The log shall contain copies of completed maintenance records and a sequential listing, by job number, of maintenance performed on packaging. The user copies of maintenance records should be kept for three years, after which they may be destroyed.

\subsection{Maintenance Due Labels}

Upon completion of annual maintenance, the maintenance facility shall affix, next to the name plate, a maintenance due label showing the month maintenance was performed. The packaging is considered Out-of-Service on the last day of the month shown on this label (i.e., if annual maintenance is performed on September 15, 2002, the packaging may be used until the end of September 2003).

Upon completion of five-year maintenance, the maintenance facility shall affix, next to the name plate, a maintenance due label showing the month maintenance was performed. The RH packaging is considered Out-of-Service after the last day of the month shown on this label (e.g., if five-year maintenance was performed on September 15, 2002, the packaging may be used until the end of September 2007). 
Figure 5.1. Maintenance Record

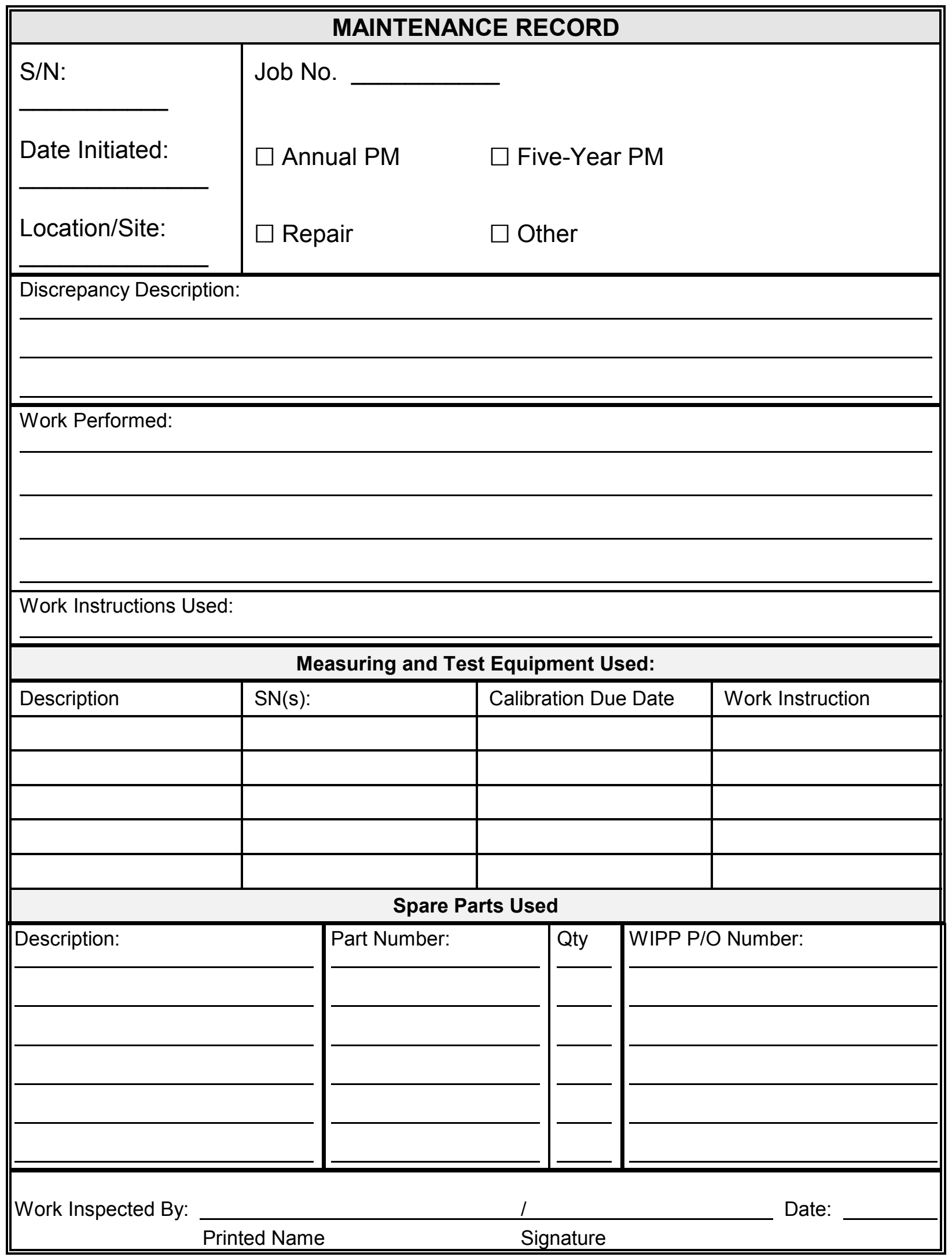


Figure 5.1 - Maintenance Record (continued)

\begin{tabular}{||}
\hline Maintenance Record - (Continuation Sheet) \\
\hline \\
\hline \\
\hline \\
\hline \\
\hline \\
\hline \\
\hline \\
\hline \\
\hline
\end{tabular}


Table 5.1 Annual Visual Inspections, Acceptance Criteria and Corrective Action

\begin{tabular}{|c|c|c|c|c|}
\hline \multicolumn{2}{|l|}{ Component/Part No. } & Acceptance Criteria & Corrective Action & $\sqrt{ }$ \\
\hline IV Gas Sampling Port Closure Bolt & $(2078-200-10)$ & No damaged threads or damaged head & Replace per WI-RH.01 & \\
\hline IV Gas Sampling Port Closure Bolt Insert & $(2078-200-17)$ & No damaged threads or damaged sealing surface & Replace per WI-RH.05 & \\
\hline IV Backfill Port Closure Bolt & $(2078-200-11)$ & No damaged threads or damaged head & Replace per WI-RH.01 & \\
\hline IV Backfill Port Closure Bolt Insert & $(2078-200-16)$ & No damaged threads or damaged sealing surface & Replace per WI-RH.05 & \\
\hline IV Seal Test Port Closure Bolt & $(2078-200-12)$ & No damaged threads or damaged head & Replace per WI-RH.01 & \\
\hline IV Seal Test Port Closure Bolt Insert & $(2078-200-18)$ & No damaged threads or damaged sealing surface & Replace per WI-RH.05 & \\
\hline IV Lid Closure Bolt & $(2078-200-13)$ & No damaged threads or damaged head & Replace per WI-RH.03 & \\
\hline IV Lid Closure Bolt Threaded Insert & $(2078-200-15)$ & No damaged threads or damaged sealing area & Replace per WI-RH.05 & \\
\hline IV Alignment Pins & $(2078-200-19)$ & No damage to pin & Replace per WI-RH.04 & \\
\hline IV Upper, Lower and Middle Flange Sealing & Surfaces & $\begin{array}{l}\text { No scratches causing leakage or finish >125 RMS } \\
\text { micro-finish }\end{array}$ & Repair per WI-RH.06 & \\
\hline IV Shell Wall Surfaces & & $\begin{array}{l}\text { No gouges or scratches causing wall thickness to } \\
\text { be }<0.375 \text {-in., or weld cracks or punctures }\end{array}$ & Repair per WI-RH.07 & \\
\hline IV Visible Body Inner Surfaces & & No signs of corrosion & NCR for disposition & \\
\hline OC Gas Sampling Port Closure Bolt & $(2078-300-10)$ & No damaged threads or damaged head & Replace per WI-RH.01 & \\
\hline OC Gas Sampling Port Closure Bolt Insert & $(2078-300-15)$ & No damaged threads or damaged sealing surface & Replace per WI-RH.05 & \\
\hline OC Seal Test Port Closure Bolt & $(2078-300-11)$ & No damaged threads or damaged head & Replace per WI-RH.01 & \\
\hline OC Seal Test Port Closure Bolt Insert & $(2078-300-14)$ & No damaged threads or damaged sealing surface & Replace per WI-RH.05 & \\
\hline OC Lid Closure Bolts & $(2078-300-12)$ & No damaged threads or damaged head & Replace per WI-RH.03 & \\
\hline
\end{tabular}




\begin{tabular}{|c|c|c|c|c|}
\hline \multicolumn{2}{|c|}{ Component/Part No. } & Acceptance Criteria & Corrective Action & $\checkmark$ \\
\hline OC Lid Closure Bolt Insert & $(2078-300-13)$ & No damaged threads or damaged sealing surface & Replace per WI-RH.05 & \\
\hline OC Alignment Pins & $(2078-300-16)$ & No damage to pins & Replace per WI-RH.04 & \\
\hline Impact Limiter Bolts & $\begin{array}{l}\text { Upper }(2078-400-10) \\
\text { Lower }(2078-400-11)\end{array}$ & No damaged threads or damaged head & Replace per WI-RH.03 & \\
\hline Impact Limiter Bolt Insert & $(2078-400-13)$ & No damaged threads or damaged sealing surface & Replace per WI-RH.05 & \\
\hline $\begin{array}{l}\text { OC Upper and Lower Flange Sealir } \\
\text { and Flats) }\end{array}$ & Surfaces (Grooves & $\begin{array}{l}\text { No scratches causing leakage or finish >125 RMS } \\
\text { micro-finish }\end{array}$ & Repair per WI-RH.07 & \\
\hline OC Visible Shell Inner Wall Surface & & $\begin{array}{l}\text { No gouges causing wall thickness to be }<1.00 \text { in., } \\
\text { or weld cracks, or punctures }\end{array}$ & Repair per WI-RH.07 & \\
\hline Plastic Pipe Plugs & $(2078-400-15)$ & $\begin{array}{l}\text { Properly tightened (+/- } 1 / 8 \text { in. from surface }) \text { and not } \\
\text { missing }\end{array}$ & Replace per WI-RH.04 & \\
\hline Tamper Indicating Seal Assembly & $(2078-400-14)$ & Pad eyes are not bent or missing & Replace per WI-RH.04 & \\
\hline \multicolumn{5}{|l|}{ Impact Limiters } \\
\hline Impact Limiter Lift Lug Assembly & $(2078-400-16)$ & Hinge not damaged or missing parts & Replace per WI-RH.04 & \\
\hline Foam & & $\begin{array}{l}\text { Deviations from design requirements which } \\
\text { prevent intended function, including cracks or } \\
\text { voids and egress of moisture }\end{array}$ & $\begin{array}{l}\text { Repair depends on condition } \\
\text { noted. Contact the M\&O } \\
\text { contractor. }\end{array}$ & \\
\hline Impact Limiters & & $\begin{array}{l}\text { Dents, cuts and/or punctures, indications of loss of } \\
\text { weld integrity and general cleanliness }\end{array}$ & $\begin{array}{l}\text { Repair depends on condition } \\
\text { noted. Contact the M\&O } \\
\text { contractor. }\end{array}$ & \\
\hline OC Thermal Shield Inspection & & $\begin{array}{l}\text { No dents, cuts and/or punctures, indications of } \\
\text { loss of weld integrity and general cleanliness }\end{array}$ & $\begin{array}{l}\text { Repair depends on condition } \\
\text { noted. Contact the M\&O } \\
\text { contractor }\end{array}$ & \\
\hline
\end{tabular}


Table 5.1 Annual Visual Inspections, Acceptance Criteria and Corrective Action

\begin{tabular}{||l|l|l|l|}
\hline \multicolumn{1}{|c|}{ Component/Part No. } & \multicolumn{1}{|c|}{ Acceptance Criteria } & \multicolumn{1}{|c|}{ Corrective Action } \\
\hline Trunnions & Excessive wear, galling, or distortion & $\begin{array}{l}\text { Repair depends on condition } \\
\text { noted. Contact the M\&O } \\
\text { contractor. }\end{array}$ \\
\hline IV/OC Painted Markings & Markings are clear and not worn & $\begin{array}{l}\text { Repair depends on condition } \\
\text { noted. Contact the M\&O } \\
\text { contractor. }\end{array}$ \\
\hline
\end{tabular}

\section{Table 5.2 Annual Component Inspection, Acceptance Criteria and Corrective Action}

\begin{tabular}{||l|l|l||}
\hline \hline \multicolumn{1}{|c|}{ Component } & \multicolumn{1}{c|}{ Acceptance Criteria } & \multicolumn{1}{|c||}{ Corrective Action } \\
\hline OC/IV O-ring Seal Surfaces & 125 micro-inch finish or better & Repair per WI-RH.06 \\
\hline IV Bottom Forging Exposed Surfaces & 1.45 in. or greater on UT measurement & Repair per WI-RH.07 \\
\hline OC Bottom Forging Exposed Surfaces & 4.950 in. or greater on UT measurement & Repair per WI-RH.07 \\
\hline IV Inner Shell Wall Exposed Surfaces & 0.325 in. or greater on UT measurement & Repair per WI-RH.07 \\
\hline OC Inner Shell Wall Exposed Surfaces & 0.950 in. or greater on UT measurement & Repair per WI-RH.07 \\
\hline IV Lid Exposed Surfaces & 6.450 in. or greater on UT measurement & Repair per WI-RH.07 \\
\hline OC Lid Exposed Surfaces & 5.950 in. or greater on UT measurement & Repair per WI-RH.07 \\
\hline IV/OC Port Closure Bolt O-ring Seal Grooves & No nicks, scratches or burrs & Replace per WI-RH.01 \\
\hline \hline
\end{tabular}

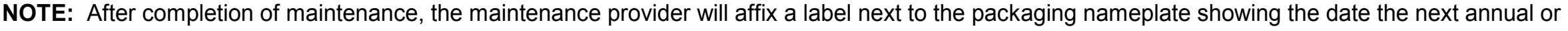
five-year maintenance is due. Packaging is considered out-of-service on the last day of the month shown on the label if maintenance has not been performed. 
DOE/WIPP 02-3283

Rev. 0

Page 44 of 55

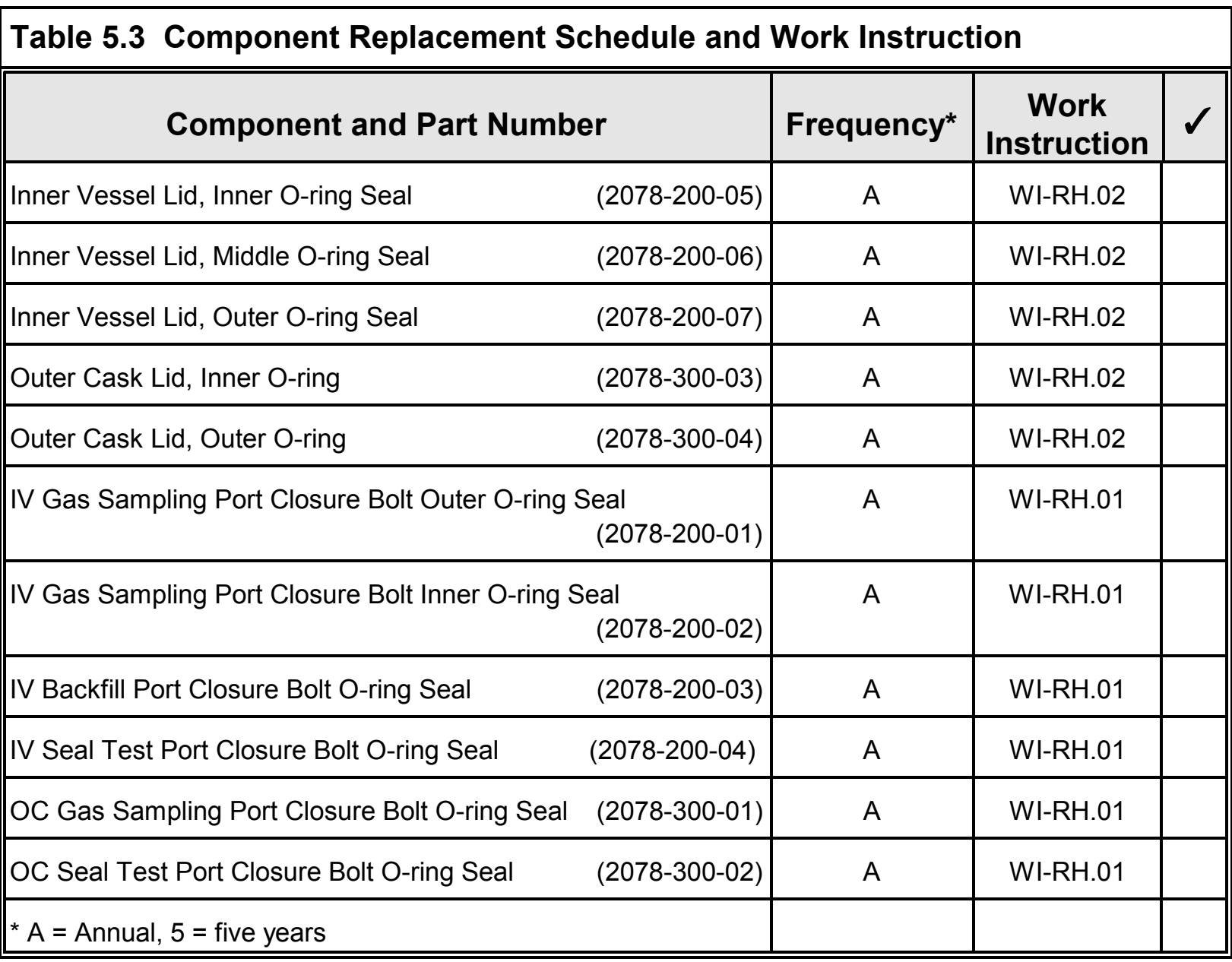

\subsection{PACKAGE MAINTENANCE LEAKAGE RATE TESTING}

DOE/WIPP 02-3285, RH Packaging Maintenance Manual, for maintenance leakage rate testing is available on the internet at: http://www.wipp.ws/library/t2omi/t2omi.htm.

\subsection{PACKAGE STRUCTURAL PRESSURE TESTING}

DOE/WIPP 02-3285, RH Packaging Maintenance Manual, for structural pressure testing is available on the internet at: http://www.wipp.ws/library/t2omi/t2omi.htm. 


\section{Attachment A - Work Instruction Format}

\section{A.1 Preparing Work Instructions for Periodic Maintenance or Initial Release}

All packaging work/periodic maintenance instructions will be written using the following work instruction format. The following descriptions and examples will aid in writing work instructions.

\section{- Title}

A short description of the work or periodic maintenance to be performed, along with the serial number of the packaging.

- Instruction Number

Assigned by the WIPP M\&O contractor. After the instruction number, enter the revision number.

- Page _ of _ _

Form page number

- Approval Signature

- $\quad$ Applicable Drawings

Drawings applicable to the work instruction. These may be SARP drawings or additional shop drawings required to complete the task.

- $\quad$ SARP Requirements

A short narrative of the SARP requirement, referencing the appropriate SARP chapter and/or section(s).

- $\quad$ Special Tools Required

Special tools required to complete the task.

- $\quad$ Spare Parts Required

All packaging spare parts required to complete the task.

- $\quad$ Materials Required

All materials required to complete the task.

- $\quad$ Safety Requirements

Safety precautions needed to complete the task.

- $\quad$ Prerequisite Conditions

All required prerequisite conditions. 
- Instruction steps

Detailed procedural steps needed to follow to complete the task.

- Verification Requirements

All verification requirements (e.g., leak-tests, material certification, etc.) required to complete the test.

- Written By:

Signature of person completing the work instruction

- $\quad$ Approved By: QA

Signature of QA Manager

- $\quad$ Approved By: Transportation Programs

Signature of Transportation Program Manager

Appropriate signatures shall be provided for all signature blocks.

\section{A.2 Revising Existing Work Instructions}

The revision will require the same approval as the original instruction. Revisions may be initiated in writing from a user to the WIPP M\&O Contractor RH Packaging Maintenance Engineer.

The WIPP M\&O Contractor RH Packaging Maintenance Engineer can be reached during normal hours at (505) 234-7252. After business hours, call the CMR at (505) 234-8125/8457 for communication of relevant items.

\section{A.3 Cancellation of Existing Work Instructions}

Approvals for cancellation will be made by the WIPP M\&O Contractor RH Packaging Maintenance Engineer. A copy shall be provided to the CBFO. The cancellation letter shall be attached to the original work instruction and dispositioned per DOE-CAO-94-1001, Information Management Plan. The canceled work instruction and all references to the canceled work instruction shall be deleted from this document through the normal change and revision procedure, and changes will be distributed to all user sites. 


$\begin{array}{lll}\text { DOE/WIPP 02-3283 } & \text { Rev. } 0 & \text { Page } 47 \text { of } 55\end{array}$

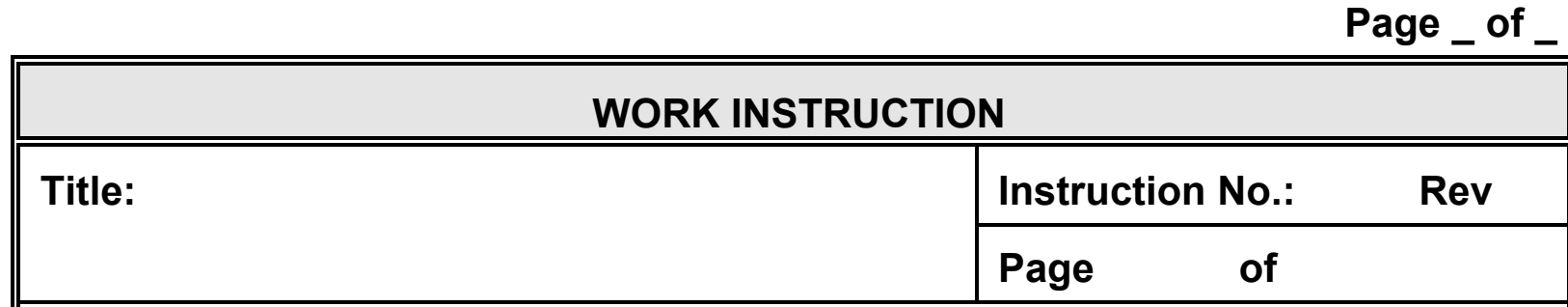

Applicable Drawings:

SARP Requirements:

Special Tools Required:

Spare Parts Required:

Materials Required:

Safety Requirements:

Prerequisite Conditions: 


\begin{tabular}{||lc||}
\hline \multicolumn{1}{|c||}{ Page_of } \\
\hline \hline WORK INSTRUCTION & \\
\hline Instruction No. Continued & Page of \\
\hline Instruction Steps: & \\
\\
\end{tabular}




\begin{tabular}{|lll}
\hline DOE/WIPP 02-3283 & Rev. 0 & Page 49 of 55 \\
\hline
\end{tabular}

\begin{tabular}{||lc||}
\hline \multicolumn{1}{|c||}{ PORK INSTRUCTION } \\
\hline \hline Instruction No. Continued & Page of \\
\hline Instruction Steps Continued: & \\
\hline
\end{tabular}




$\begin{array}{lll}\text { DOE/WIPP 02-3283 Rev. } 0 & \text { Page } 50 \text { of } 55\end{array}$

\begin{tabular}{||lc||}
\hline \multicolumn{1}{|c|}{ WORK INSTRUCTION } & Page_of \\
\hline \hline Instruction No. Continued & Page of \\
\hline Instruction Steps Continued: & \\
& \\
\hline Verification Requirements: & \\
\hline Written by: & Date: \\
\hline Approved by: QA & Date: \\
\hline Approved by: Transportation Programs & Date: \\
\hline \hline
\end{tabular}




\section{Attachment B - Approved Work Instructions}

NOTE: All work instructions listed below can be performed by the maintenance vendor. Work instructions WI-RH.01 through WI-RH.05, and WI-RH.07 are considered to be within the capabilities of a user to perform (except any weld work that needs to be done which can be accomplished by the maintenance vendor).

NOTE: Conditions may warrant that only specific steps of a work instruction are required for corrective action. Consequently, it is acceptable to perform only the necessary steps and to mark with "N/A" the ones not needed.

- WI-RH.01, Replacement of IV/OC Port Closure Bolts and O-rings

- WI-RH.02, Replacement of IV/OC Lid Main O-Rings

- WI-RH.03, Replacement of Lid Closure and Impact Limiter Attachment Bolts

- WI-RH.04, Replacement of Miscellaneous Parts Not Requiring Detailed Instructions

- WI-RH.05, Cleaning IV/OC Threads, Impact Limiter Threads, Threaded Inserts and Port Inserts

- WI-RH.06, IV/OC Sealing Surface Finish Inspection

- WI-RH.07, Minor Repair of IV and OC Lid and Body Exposed Surfaces

- WI-RH.08, Annual and Five-Year Maintenance Inspections 


\section{Attachment C - RH Packaging Qualification Requirements}

The following guidelines establish the minimum training requirements for $\mathrm{RH}$ packaging operations. User site qualification cards SHALL include these items as a minimum. Users may separate the requirements to address different skills used to load a $\mathrm{RH}$ packaging per site requirements if all areas are addressed by each site.

I. References

A. OPERATIONS

1. DOE/WIPP 02-3283, RH Packaging Program Guidance

2. DOE/WIPP 02-3284, RH Packaging Operations Manual

3. NRC-Docket-71-9212/Rev. 2, Safety Analysis Report for RH-TRU 72-B Waste Shipping Package

4. DOE-STD-1090-2001, Hoisting and Rigging Standard

5. DOE/WIPP 02-3285, RH Packaging Maintenance Manual

B. MAINTENANCE

1. DOE/WIPP 02-3283, RH Packaging Program Guidance

2. DOE/WIPP 02-3284, RH Packaging Operations Manual

3. NRC-Docket-71-9212/Rev. 2, Safety Analysis Report for RH-TRU 72-B Waste Shipping Package

4. DOE/WIPP 02-3285, RH Packaging Maintenance Manual

C. TRAILER LOADING AND UNLOADING

1. DOE/WIPP 02-3283, RH Packaging Program Guidance

2. DOE/WIPP 02-3284, RH Packaging Operations Manual

3. NRC-Docket-71-9212/Rev. 2, Safety Analysis Report for RH-TRU 72-B Waste Shipping Package

4. DOE-STD-1090-2001, Hoisting and Rigging Standard

II. Knowledge

\section{A. PACKAGING OPERATIONS}

1. Discuss the IV/OC lid removal process (ref. A.2).

2. Describe the purpose and identify the type of seals used on the packaging (ref. A.1, 2, 3). 
3. Describe the physical construction of the packaging assembly (ref. A.1, 2, 3).

4. State the lubrication requirements for the O-ring seals (ref. A.2).

5. Identify the tools required for packaging operation and discuss the function of each tool (ref. A.1, 2).

6. Identify and explain the purpose of the following packaging components (ref. A.1, 2).
a. Lid O-rings
b. Closure bolts
c. Impact limiters
d. Pick points
e. Port closure bolts
f. Seal, gas sampling, and backfill ports

7. Discuss the limits associated with packaging operation (i.e., pressure, radiation levels) (ref. A.1, 2, 3).
a. Maximum total weight of cask
b. Maximum allowable weight of payload
c. Maximum RAD levels in cask
d. Maximum RAD levels on the surface
e. Maximum design pressure in cask
f. Maximum thermal watts per canister

8. State the location of the security seal (ref. A.1, 2).

9. Describe the precautions that should be taken when removing the OC/IV lids (ref. A.1, 2, 4).

10. Describe the precautions that should be taken when installing the lids (ref. A.2, 3).

11. State the inspection process for the IV, OC, and impact limiters (ref. A.2, 4).

12. State the torque requirements for: (A.2)
a. Lid closure bolts
b. Port closure bolts
c. IV Port closure bolt

\section{B. PACKAGING MAINTENANCE}

1. Describe the method of cleaning the port threads (ref. B.1, 2).

2. Discuss the different types of leak testing required for the packaging and when each must be performed (ref. B.1, 2, 4).

3. Identify the materials needed to clean the sealing surfaces (ref. B.1, 2). 
4. State the process for replacing threaded inserts (Keensert only) (ref. B.1).

5. Describe how to complete a packaging maintenance record (ref. B.1).

6. State the record retention requirement for packaging maintenance records (ref. B.1).

C. TRAILER LOADING AND UNLOADING ${ }^{1}$

1. Describe the impact limiter removal process (ref. C.1, 2, 3, 4).

2. Describe the process of removing the packaging from the trailer (ref. C.1, 3, $4)$.

3. Discuss what is inspected on the trunnion tie-down assembly (ref. C.2).

4. State the torque requirement for the trunnion tie-down cap bolts, and impact limiter attachment bolts (ref. C.2, 3).

5. Describe how to lubricate trunnion tie-downs (ref. C.2).

6. State the maximum load limit for the trailer (ref. C.1, 2).

7. Describe the process of installing trunnion tie-downs (ref. C.2).

\section{Operations}

\section{A. PACKAGING OPERATION}

1. Perform OC lid removal (ref. A.2).

2. Perform IV lid removal (ref. A.2).

3. Load a cannister into IV (ref. A.2).

4. Inspect OC lid assembly (ref. A.2).

5. Inspect OC lower assembly (ref. A.2).

6. Inspect IV lid assembly (ref. A.2).

7. Inspect IV lower assembly (ref. A.2).

8. Inspect IV/OC components (ref. A.1, 2).

9. Perform IV lid installation (ref. A.2).

10. Perform OC lid installation (ref. A.2).

\footnotetext{
${ }^{1}$ This section applies only to those sites that remove the packaging from the trailer.
} 


\section{B. PACKAGING MAINTENANCE}

1. Replace a lid O-ring (ref. B.1).

2. Replace IV/OC lid closure bolt threaded insert (ref. B.1).

3. Complete Maintenance Record (ref. B.1).

C. TRAILER LOADING AND UNLOADING

1. Remove impact limiters (ref. C.1, 2, 3, 4).

2. Remove trunnion tie-down caps (ref. C.1, 2).

3. Unload a packaging from a trailer (ref. C.1, 2, 3, 4).

4. Load a packaging on the trailer (ref. C.1, 2, 3, 4).

5. Perform trunnion tie-down assembly inspections (ref. C.1, 2).

6. Install trunnion tie-down caps (ref. C.1, 2).

7. Install impact limiters (ref. C.1, 2, 3). 